\title{
Marine enzymes and food industry: insight on existing and potential interactions
}

\author{
Pedro Fernandes ${ }^{1,2 *}$ \\ 'Department of Bioengineering, Centre for Biological and Chemical Engineering, Institute for Biotechnology and Bioengineering, Instituto Superior Técnico, \\ Universidade de Lisboa, Lisboa, Portugal \\ 2 Faculdade de Engenharia, Universidade Lusófona de Humanidades e Tecnologias, Lisboa, Portugal
}

\section{Edited by:}

Donatella De Pascale, National

Research Council- CNR, Italy

Reviewed by:

Marco P. C. Marques, University

College London, UK

Yu-Zhong Zhang, Shandong

University, China

\section{${ }^{*}$ Correspondence:}

Pedro Fernandes, Department of Bioengineering, Centre for Biological and Chemical Engineering, Institute for Biotechnology and

Bioengineering, Instituto Superior Técnico, Universidade de Lisboa, Av. Rovisco Pais, 1049-001 Lisboa, Portugal

e-mail:pedro.fernandes@ tecnico.ulisboa.pt
Evidence that support the marine environment as source of useful biocatalysts for application in several areas of industry pile up, both as scientific reports or patent applications. Marine microorganisms have to endure habitats characterized by extreme conditions of salinity, temperature or pressure. Their enzymes present concomitant features, viz. thermostability or halostability, which are appealing for practical applications. The food sector is a field where enzymes are used, given their specificity, compliance with strict regulations, relatively mild operational conditions required and environmental friendly nature. The specific features presented by marine enzymes can be advantageously used both for process improvement or to develop new processes and products. In the present review the role of relevant types of enzymes for the food sector is described and recent findings on those enzymes from marine are put into context. The information provided is illustrative that in spite of the relative novelty concerning the use of marine enzymes within the scope of the food sector, some processes have reached commercial status and promising results are being obtained with several others. Moreover, there is still a vast field of resources for enzyme activity to be explored, namely since the screening process that has been considerably improved with the contribution of metagenomic libraries. It can thus be considered that future and exciting developments can be expected concerning the use of marine enzymes in the food and feed areas.

Keywords: biocatalysis, marine enzymes, food processing, food industry, marine microorganisms

\section{INTRODUCTION}

The marine environment conveys a diversity of conditions that provides unique habitats for the organisms living therein (Imhoff et al., 2011). High salinity is naturally a common feature, but low temperatures can occasionally alternate with high temperature environments, such as those conveyed by thermal vents. Increased depth means increased pressure and reduced light; nutritional rich regions co-exist with locations where those resources are scarce or relatively uncommon. Therefore, adapted organisms are required to endure such extreme conditions (Zhang and Kim, 2010; Trincone, 2013a). These particular features of marine organism are naturally anchored in enzymes with concomitantly unique and appealing characteristics, which have resulted in an increased interest in the prospection of marine resources for enzymes with applications in biotechnology (Trincone, 2011; Dionisi et al., 2012; Freitas et al., 2012; Arnosti et al., 2014). This trend, which encompasses the use of enzymes from marine sources within the food industry includes a vast array of applications, such as food processing, incorporation in formulations as food additives and production of given compounds (Trincone, 2011; Freitas et al., 2012; Nielsen and Nielsen, 2012). Besides the well-established specific nature of enzyme action, the application of marine enzymes for these applications aims to capitalize on specific features, viz. halotolerance, thermophilic or psychrophilic nature, conveyed by the environment their microbial hosts have to withstand. The identification of enzymes from marine sources involves both traditional screening methods, albeit performed through high throughput methodologies, as well as metagenomic libraries, where enzyme genes are cloned and expressed in suitable hosts (Kennedy et al., 2010). Some of these enzymes fit in roles of interest for the food industry. The following sections briefly summarize the action of significant enzymes in the food sector and highlight related recent findings involving such enzymes from marine, preferably microbial, sources.

\section{AGARASES}

Agarases are used in the hydrolysis of agar, a colloid extracted from seaweeds, which is commonly used as an additive in food processing, since it can act as an emulsifying, gelling and stabilizing agent. Agar is a mixture of agarose and agaropectin, the former being the larger fraction. Agarose is a polysaccharide typically with a molecular weight of $120 \mathrm{kDa}$, composed of repeating units of 1,3-linked $\beta$-D-galactopyranose and 1,4-linked 3,6-anhydro- $\alpha$-L-galactopyranose. Agaropectin comprehends a heterogeneous mixture of smaller molecules with the same backbone as agarose but displaying an ionic nature, with acidic groups (viz. sulfate, pyruvate) as intrinsic components (Delattre et al., 2011). Agarose can be hydrolyzed to oligosaccharides, which are 
considered of particular interest in the production of functional foods (Chen et al., 2006; Enoki et al., 2010; Ramnani et al., 2012). Hydrolysis can be promoted by either $\alpha$-agarases (E.C. 3.2.1.158), which cleave $\alpha-1,3$ linkages to produce agarooligosaccharides 3,6anhydro-L-galactose (Anr) residues at their reducing ends; or by $\beta$-agarases (E.C. 3.2.1.81), which cleave $\beta-1,4$ linkage to produce neoagarooligosaccharides with $\mathrm{D}$-galactose residues at their reducing ends (Fu and Kim, 2010; Chi et al., 2012). Agarases may display either endo- or exo-activity, or both actitivities (Chi et al., 2012). Most of the agarases identified to date are $\beta$-agarases (Chi et al., 2012; Han et al., 2013), while only $\alpha$-agarases from Alteromonas agarlyticus GJ1B (Potin et al., 1993), Thalassomonas sp. JAMB-A33 (Ohta et al., 2005) and Pseudoalteromonas sp. BL-3 (Lee et al., 2005) have been reported, all from marine sources. This pattern has been ascribed to the low activity and productivity of $\alpha$-agarases as compared to $\beta$-agarases, which makes their isolation difficult and considerably limits the interest toward industrial application (Seok et al., 2012). Efforts to overcome this drawback include optimization of fermentation conditions (Hassairi et al., 2001 ) and the production of recombinant $\alpha$-agarases, which have met some success using Saccharomyces cerevisiae as host strain for expression of the $\alpha$-agarase from Thalassomonas sp. JAMB-A33 (Ohta et al., 2005). $\alpha$-Agarases are included in a new family of glycoside hydrolases (GH), GH96 (Flament et al., 2007), based on the similarity of amino acid sequence (www.cazy.org, assessed on June 30, 2014). $\beta$-Agarases have been isolated from several marine source, most notably Alteromonas sp., Bacillus cereus, Cytophaga sp., Pseudoalteromonas sp., Pseudomonas sp. and Vibrio sp. (Hu et al., 2009; Fu and Kim, 2010; Chi et al., 2012; Vijayaraghavan and Rajendran, 2012) $\beta$-Agarases can be classified into four $\mathrm{GH}$ families, GH16, GH50, GH86, and GH118, based on the similarity of amino acid (www.cazy.org, assessed on June 30, 2014). Typically, $\beta$-agarases are divided into types I and II, depending on substrate specificity and product profile. Thus, type I cleaves agarose into neoagarotetraose, while the major product of type II is neoagarobiose (Temuujin et al., 2012). Several reports on the identification and characterization of $\beta$-agarases have been presented recently, that highlight the topicality of this matter. Within this scope, cloning of $\beta$-agarase genes was performed in several cases. Thus, the agaXa from Catenovulum sp. X3, a seawater bacterium, was expressed in Escherichia coli BL21 (Xie et al., 2013). The recombinant enzyme, with an estimated molecular weight of $52 \mathrm{kDa}$, was associated with the GH118 family and exhibited an optimal temperature of $52^{\circ} \mathrm{C}$ (Table 1). The later temperature was in excess of the optimum temperatures of other agarases from the same family. Moreover the enzyme was stable at temperatures under $42^{\circ} \mathrm{C}$, at which more than $95 \%$ of the maximal activity was retained. This is a feature of interest since the gelling temperature of agar is around $40^{\circ} \mathrm{C}$. With agarose as substrate, the endolytic enzyme displayed $\mathrm{K}_{\mathrm{M}}$ (Michaelis constant) of $10.5 \mathrm{mg} / \mathrm{ml}$ and $V_{\max }$ (maximum reaction rate) of $588.2 \mathrm{U} / \mathrm{mg}$, where the end products of hydrolysis had even degrees of polymerization between 6 and 12 (neoagarohexaose, neoagarooctaose, neoagarodecaose, and neoagarododecaose). Activity unit was defined as the amount of enzyme required to release $1 \mu \mathrm{mol}$ of reducing sugars per minute under established conditions.

The $\beta$-agarase gene agy 1 from Saccharophagus sp. AG21, a marine bacterium, was cloned and overexpressed as a His-tagged recombinant $\beta$-agarase in E.coli (Lee et al., 2013). The recombinant enzyme, which fit within the GH16 family, had an estimated molecular weight of $69 \mathrm{kDa}$. When incubated at $45^{\circ} \mathrm{C}$, the enzyme retained about $80 \%$ of the initial activity after $150 \mathrm{~min}$, a time gap that decreased to half when incubated at $50^{\circ} \mathrm{C}$. Metal ions and ion chelators had disparate effects on enzyme activity (Table 1). With agarose as substrate the enzyme displayed an activity of $85 \mathrm{U} / \mathrm{mg}$ and the final products of hydrolysis were neoagarotetraose and

Table 1 | Some recently identified agarases from marine sources.

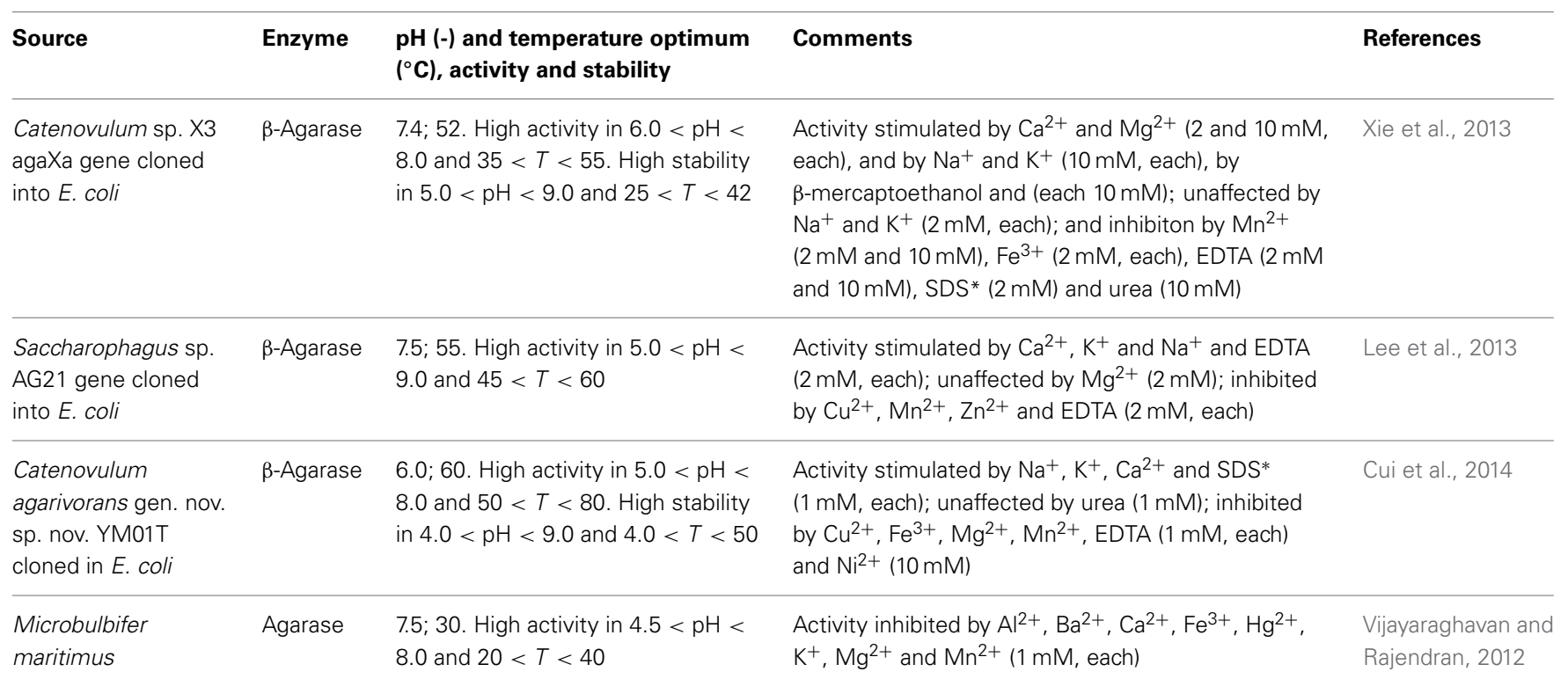

${ }^{*}$ SDS, sodium dodecylsulfate. 
neoagarohexaose. The same product profile from agarose was observed when the YM01-3 gene from Catenovulum agarivorans gen. nov. sp. nov. $\mathrm{YM} 1^{\mathrm{T}}$ seawater bacterium was cloned and overexpressed in E. coli JM109 (Cui et al., 2014). The recombinant enzyme, which was also included in the GH16 family, had an estimated molecular weight of $46.9 \mathrm{kDa}$, but exhibited a higher thermal stability and activity than the one from Saccharophagus sp. AG21, as well as when compared with several other agarases. Thus, not only it was stable below $50^{\circ} \mathrm{C}$, at which temperature retained $90 \%$ of the initial activity, but it retained $13 \%$ activity after $1 \mathrm{~h}$ of incubation at $80^{\circ} \mathrm{C}$, and displayed $V_{\max }$ of $1.14 \times$ $10^{4} \mathrm{U} / \mathrm{mg}$ and $\mathrm{K}_{\mathrm{M}}$ of $3.78 \mathrm{mg} / \mathrm{ml}$. More details about this enzyme are given in Table 1. In the overall this recombinant enzyme was considered promising for application in a cost effective industrial application.

Cloning and expression of genes encoding putative agarases from the marine bacterium Zobellia galactanivorans into E. coli BL21 was also the strategy used to gain insight on the enzymatic complex accountable for agarose hydrolysis (Hehemann et al., 2012). Accordingly, the authors were able to establish a scenario for the concerted action of three agarases, each with a specific role: one of these, a highly specific $\beta$-agarase, AgaD, would be responsible for the production of long oligosaccharide chains for the action of the remaining agarases. These included an agarase, AgaA, targeted for the degradation of the regular neoagarobiose fibers that form the core of agar gels, and possibly being able to be involved in the degradation of solid substrate; and $\mathrm{AgaB}$, assigned to the hydrolysis of soluble agarooligosaccharides. A fourth agarase of the complex system was also identified but its role remained unclear.

Halococcus sp. 197A was also identified as a producer of $\beta$ agarase (Minegishi et al., 2013). The extracellular enzyme, with a molecular weight of $55 \mathrm{kDa}$ and a $\mathrm{pH}$ optimum of 6.0 , was thermostable. Thus, it displayed a temperature optimum of $70^{\circ} \mathrm{C}$ and the ability to retain $90 \%$ of the initial activity at $65-80^{\circ} \mathrm{C}$ and $50 \%$ activity at $95^{\circ} \mathrm{C}$, in either case after $1 \mathrm{~h}$ of incubation. Incubation for $30 \mathrm{~min}$ under $100^{\circ} \mathrm{C}$ led to full deactiovation, a behavior that was partially mitigated when incubation was performed in the presence $\mathrm{CaCl}_{2}(10 \mathrm{mM})$, as $17 \%$ of the initial activity was retained. This can suggest the presence of a calcium binding site calcium ion in such a location that stabilizes a part of the agarase that is involved in the unfolding processes for thermal deactivation (Veltman et al., 1998). Moreover, the enzyme remained active for $\mathrm{NaCl}$ concentrations within $0.3 \mathrm{M}$ to $4.75 \mathrm{M}$, with maximal activity at $3.5 \mathrm{M}$. Activity pattern was roughly similar in the presence of $\mathrm{KCl}$ (from $0.3 \mathrm{M}$ to $3.5 \mathrm{M}$ ), suggesting its ability to operate efficiently in saline environments. The gram negative Microbulbifer maritimus bacterium was also identified as producer of an extracellualar agarase of $75.2 \mathrm{kDa}$ (Vijayaraghavan and Rajendran, 2012). The $\mathrm{K}_{\mathrm{M}}$ for agarose was of $3 \mathrm{mM}$. A rather uncommon double-bell shaped curve was observed when the effect of $\mathrm{pH}$ in activity was evaluated. Since a single band was observed in SDS-PAGE, the possibility of two agarases being present, with a major form active at $\mathrm{pH} 7.5$ and a minor fraction active at pH 5.0 is unlikely (Ye et al., 2011). It can be thus suggested the presence of two isoforms of the agarase (Farnet et al., 2002), with activity peaking at pH 7.5 (Table 1).
The enzyme lost activity after 6 days of storage at temperatures above $20^{\circ} \mathrm{C}$, although if stored at $-20^{\circ} \mathrm{C}$ it remained stable after 10 days. A $\beta$-agarase from of extracelular nature was isolated from Alteromonas GNUM-1, no relevant information was provided on the enzyme, apart from the molecular weight $(30 \mathrm{kDa})$ (Jonghee and Hon, 2012).

\section{AMYLASES}

These enzymes act on starch and starch derivatives (Table 2). Starch consists of a mixture of amylose and amylopectin, where $\alpha$ D-glucopyranosyl units are bound together, either by essentially 1,4 links or by 1,4 links and 1,6 links, respectively. Amylopectin is the major form on a 3 to 1 ratio to amylose in most starches (Bertoft, 2004).

Starch hydrolysates and other derivatives are widely used in food and beverage industry. Starch processing through hydrolysis requires however relatively high temperatures, since liquefaction occurs at temperatures that may exceed $100^{\circ} \mathrm{C}$, and saccharification takes place at temperatures within $50-90^{\circ} \mathrm{C}$. Enzymes able to cope with such environment are therefore of interest. Furthermore, the hydrolysis of starch to glucose or small oligosaccharides, and ultimately its inversion to fructose is a multienzymatic process. Typically amylases partially hydrolyze starch to dextrins during the liquefaction stage. Dextrins are then further hydrolyzed either to high and very high maltose syrups or to high dextrose syrups. In the former case, amylases are further involved, often aided by pullulanases when very high maltose syrups are envisaged. In the later case glucoamlyases, again often in a cocktail with pullulanases, are used to hydrolyze dextrins to glucose, and yield dextrose and high dextrose syrup. Glucose in high dextrose syrups can then be partially isomerized to fructose, to yield a high fructose corn syrup (Fernandes, 2010a,b). Representative applications of the starch hydrolysates are given in Table 3. Besides temperature, other operational conditions, viz. $\mathrm{pH}$ environment and metal ions requirements, often differ for each step, which increases complexity and cost. Hence, the quest

Table 2 | Hydrolytic action on starch and related polysaccharides and enzyme (Aiyer, 2005).

\begin{tabular}{ll}
\hline Action & Enzyme \\
\hline $\begin{array}{ll}\text { Hydrolysis of } \alpha-1,4 \text {-bonds while } \\
\text { by-passing } \alpha-1,6 \text {-bonds (endo-action) }\end{array}$ & $\alpha$-Amylase (EC 3.2.1.1) \\
\hline $\begin{array}{ll}\text { Hydrolysis of } \alpha-1,4-\text { bonds, unable to } \\
\text { by-pass } \alpha-1,6 \text {-bonds (exo-action) }\end{array}$ & $\beta$-Amylase (EC 3.2.1.2) \\
\hline $\begin{array}{l}\text { Hydrolysis of } \alpha-1,4-\text { and } \alpha-1,6-b o n d s \\
\text { Hydrolysis of } \alpha-1,6-\text { bonds }\end{array}$ & Glucoamylase (EC 3.2.1.3) \\
$\begin{array}{l}\text { Preferential hydrolysis of } \alpha-1,4-b o n d s \\
\text { in short chain oligosaccharides }\end{array}$ & $\alpha$-Glucosidase (EC 3.2.1.20) \\
\hline
\end{tabular}

Hydrolysis of starch to non-reducing cyclic D-glucosyl polymers

Cyclodextrin glycosyltransferase (cyclodextrins) 
Table 3 | Examples of applications of starch hydrolysates in the food sector (Blanchard and Katz, 2006; Parker et al., 2010; Dar, 2014).

\begin{tabular}{ll}
\hline Starch hydrolysate & Application \\
\hline $\begin{array}{l}\text { Maltose and high } \\
\text { maltose syrups }\end{array}$ & $\begin{array}{l}\text { Formulation in fat replacer recipes, stabilization of } \\
\text { semimoist product (viz pet foods, pastry fillings, } \\
\text { encapsulation of flavors and colorants }\end{array}$ \\
\hline Dextrose syrups & $\begin{array}{l}\text { To control the crystallization of sucrose in } \\
\text { confectionary, to react with nitrogenous } \\
\text { ingredients, leading to browning and caramel } \\
\text { color and flavor; to provide texture in table } \\
\text { syrups, jams and jellies. Part of blendings with } \\
\text { more potent sweeteners; to provide sweetness } \\
\text { and envisaged mouthfeel }\end{array}$
\end{tabular}

High dextrose syrups Formulation in foods as humectants or to provide bulk. Reduce water activity, decrease the freezing point and control the crystallization of water in ice creams and of sucrose in confections. Cooling mouth feel sensation

High fructose corn syrup

Sweetener in soft drinks, processed foods (viz. canned fruits, sauces, soups, baked goods) and dairy industry (yoogurt, ice cream, flavored milks)

for enzymes presenting as similar requirements as possible is only natural.

\section{$\alpha$-AMYLASES}

The isolation of thermostable amylases from marine sources has been often claimed, but occasionally conclusions are a bit overenthusiastic. There are however recent reports on actually temperature enduring $\alpha$-amylases. Of these amylases, maybe the most influential involves Fuelzyme ${ }^{\circledR}$, an $\alpha$-amylase produced and commercialized by Verenium Corporation. This is claimed to display a competitive operational range of temperatures and $\mathrm{pH}$, as compared to other commercially available amylases, and to less demanding in $\mathrm{Ca}^{2+}$ for stability, which eases further processing and decreases costs (Atichokudomchai et al., 2006; Leary et al., 2009; Nedwin et al., 2011). Accordingly, Fuelzyme ${ }^{\circledR}$ has been used in a blend for starch processing, where addition of another amylase allowed for obtaining the dextrose equivalent level adequate for sweetener production (Nedwin et al., 2011). Reports on calcium independent $\alpha$-amylases are scarce, and one that fits within this minority pattern is an amylase produced by a salt tolerant Streptomyces strain isolated from marine sediments (Chakraborty et al., 2012). Incubation in the presence of $\mathrm{Ca}^{2+}$ ( 5 and $10 \mathrm{mM}$ ) had no impact on enzyme activity, unlike other metal ions that proved inhibitory, namely $\mathrm{Hg}^{2+}$, suggestive of the presence of indole residues in the enzyme, $\mathrm{Co}^{2+}$ and $\mathrm{Cu}^{2+}$, indicating competition between protein-associated and exogenous cations. Moreover, the enzyme was thermostable, as it retained $40 \%$ of its initial activity after $48 \mathrm{~h}$ of incubation at $95^{\circ} \mathrm{C}$. This pattern was observed independently of the presence of $\mathrm{Ca}^{2+}$, unlike observed commonly for amylases, where the presence of the later ion increases stability (Fernandes, 2010a; Chakraborty et al., 2012). The amylase had an alkaline and halophilic nature, since it retained almost full initial activity at $\mathrm{pH} 9.0$ and $80 \%$ of the initial activity in the presence of $10 \% \mathrm{NaCl}$, respectively, after $48 \mathrm{~h}$ of incubation (Chakraborty et al., 2012). Also promising is an $\alpha$-amylase produced by a Bacterium sp. isolated from a marine salt farm (Pancha et al., 2010). Thus, not only a temperature optimum of $110^{\circ} \mathrm{C}$ was observed, but after $30 \mathrm{~min}$ of incubation the enzyme retained full activity at $60^{\circ} \mathrm{C}$ and $45 \%$ of the initial activity at $110^{\circ} \mathrm{C}$. Enzyme activity was inhibited by several metal ions, including $\mathrm{Ca}^{2+}$ and a sharp $\mathrm{pH}$ optimum for both activity and stability was observed at 8.0, therefore requiring $\mathrm{pH}$ adjustment for further processing toward sweetener production (Fernandes, 2010b). Geothermal vents create a particular stressful environment, particularly when temperature is considered. The temperature optimum of $90^{\circ} \mathrm{C}$ observed for an $\alpha$-amylase produced by Geobacillus sp. Iso5 is therefore concomitant with the requirements to cope with such harsh environment (Gurumurthy and Neelagund, 2012). Furthermore, since the melting temperature of the amylase remained stable between 80 and $140^{\circ} \mathrm{C}$, the authors suggested that the amylase may remain active at the latter temperature. The $\mathrm{pH}$ optimum was however of 8.0 and activity was inhibited by $\mathrm{Ca}^{2+}, \mathrm{Cu}^{2+}, \mathrm{Fe}^{2+}, \mathrm{Mg}^{2+}, \mathrm{Zn}^{2+}$ and EDTA, particularly the two later, each at a concentration of $5 \mathrm{mM}$. Again with potential application for starch processing, given the haloand thermal stability, is the $\alpha$-amylase produced by Halomonas sp. strain AAD21 (Uzyol et al., 2012). Thus, although the temperature optimum was of $50^{\circ} \mathrm{C}$, the enzyme retained full activity after $2 \mathrm{~h}$ of incubation at either 50 or $60^{\circ} \mathrm{C}$, at which temperature the activity was $60 \%$ that of the optimum. Moreover, the enzyme retained $70 \%$ of the initial activity after $2 \mathrm{~h}$ of incubation at $90^{\circ} \mathrm{C}$, although there were no data on the effect of such temperature in the initial enzyme activity. The enzyme displayed the highest activity at $2 \%(\mathrm{w} / \mathrm{v})$ sodium chloride. Above this the activity decreased to $70 \%$ of at a sodium chloride concentration of $6 \%(\mathrm{w} / \mathrm{v})$. A pH optimum of 7 was however reported.

\section{GLUCOAMYLASES}

Production of glucoamylases by marine microorganisms has also been reported. Thus, the marine yeast Aureobasidium pullulans N13d was shown to produce a glucoamylase with relevant catalytic activity at $60^{\circ} \mathrm{C}$ over potato starch. The enzyme was active even over granules, unlike most starch digesting enzymes, although gelatinized form of potato starch was favored as substrate (Li et al., 2007). In any case, glucose was the only sugar identified in the hydrolizates, suggesting thus activity over both $\alpha-1,4$ and $\alpha-1,6$ glycoside linkages Curiously, the amylolytic activity decreased when starch was from either sweet potato or corn. This feature was most noticeable when ungelatinized starch was processed, for a 10 fold decrease in activity was observed. The authors were able to establish that the activity of the enzyme over amylopectin exceeded by 1.14 fold that over amylose (and by 68 fold that over pullulan), thereby evidencing activity on specific $\alpha-1,6$ glycoside linkages. This feature could not account however for the difference in substrate specificity, since the typical amylose content gradually increases from sweet potato, to potato to corn (Liang, 2005). Nevertheless, since potato is a major source of starch, the enzyme has potential for use in commercial applications for the production of high dextrose syrups. The marine 
endophytic fungus Aspergillus sp. JAN-25 also produces a glucoamylase, which display maximal activity between 50 and $60^{\circ} \mathrm{C}$, and retains 97 and $83 \%$ of its activity at 70 and $80^{\circ} \mathrm{C}$, respectively, suggestive of a thermostable nature. Moreover the $\mathrm{pH}$ optimum was observed between 4.5 and 5.5 and the enzyme was stable down to $\mathrm{pH} 4.0$, whereas it retained retained 90 and $54 \%$ of its activity at $\mathrm{pH} 7.0$ and 10.0, respectively, indicating ease of process integration with $\alpha$-amylase enzymes. A detailed characterization of the effect of metal ions on activity was also performed, which established that, at $5 \mathrm{mM}$ concentration, $\mathrm{Cd}^{2+}, \mathrm{Cu}^{2+}, \mathrm{Fe}^{2+}, \mathrm{Fe}^{3+}$, $\mathrm{Hg}^{2+}, \mathrm{Pb}^{2+}$, and $\mathrm{Zn}^{2+}$ proved inhibitory, whereas $\mathrm{Ba}^{2+}, \mathrm{Ca}^{2+}$, $\mathrm{Mg}^{2+}, \mathrm{Mn}^{2+}$, and $\mathrm{Na}^{+}$and enhanced glucoamylase activity. Such information can be advantageously used either when a multienzyme pathway is envisaged or criteria for upstream processing of feed, prior to incubation with the enzyme is looked after (El-Gendy, 2012).

\section{PULLULANASES}

Pullulanases are commonly termed debranching enzymes as a result of their hydrolytic activity over $\alpha-1,6$ glycosidic bonds in amylopectin and related polysaccharides. These enzymes are often combined with glucoamylase for efficient saccharification of starch, thus allowing for high glucose yield (Hii et al., 2012). Given the operational conditions for starch processing, referred to in the section dedicated to amylases, thermo tolerant enzymes are looked after Marine sources have been naturally tapped as providers of such pullulanases. Within this trend $\mathrm{Wu}$ and Chen recently reported on the characterization of a pullulanase from the yeast-like fungus Aureobasidium pullulans, isolated from sea mud (Wu and Chen, 2014). The optimal conditions for pullulan hydrolysis, namely $\mathrm{pH}$ of 4.92 , a temperature of $47.9^{\circ} \mathrm{C}$ and an incubation period of $9.40 \mathrm{~h}$, were established through a central composite design, and allowed for a maltotriose content in the product and a yield of maltotriose of 92.13 and $90.23 \%$, out of an initial pullunan concentration of $31.25 \mathrm{gL}^{-1}$. The authors did not evaluate the operational stability of the enzyme, although they clearly established that $\alpha-1,6$ glycosidic activity was predominant in the enzyme preparation. This is not always the case, since debranching enzymes may also present $\alpha-1,4$ glycosidic activity, thus being termed pullulanases type II, or amylopullulanases, and proving particularly useful in starch hydrolysis (Hii et al., 2012). This is the case of a hyperthermophilic amylopullulunase produced by Thermococcus hydrothermalis, an archaeon isolated from a deep-sea hydrothermal vent (Gantelet and Duchiron, 1998). The enzyme displayed a relative activity over $70 \%$ within a $\mathrm{pH}$ range of 4.0-8.0, with an optimum at $\mathrm{pH} 5.5$, the latter being typical of pullulanases. Activity peaked at $95^{\circ} \mathrm{C}$, a figure that could be increased to $110^{\circ} \mathrm{C}$ in the presence of $1 \mathrm{mM} \mathrm{Ca}^{2+}$. Moreover, $\mathrm{Ca}^{2+}$ increased by roughly 2 -fold the activity and even more significantly the thermal stability. Thus, it allowed for the enzyme to retain about $92 \%$ of the initial activity after $4 \mathrm{~h}$ of incubation at $95^{\circ} \mathrm{C}$, whereas in the absence of the cation the half-life under the same temperature was of $10 \mathrm{~min}$. Calcium has been shown to bind with high affinity to pullulananes from archea, leading to the formation of a compact form, highly resistant to thermal denaturation (Schwerdtfeger et al., 1999). Despite of the remarkable thermal stability, the hydrolytic activity of the pullulanase is relatively low (under $50 \%$ of the maximal activity) at temperatures around $55-65^{\circ} \mathrm{C}$, where most starch saccharification processes are performed due to the thermal endurance of $\alpha$ and $\beta$-amylases commonly used (Fernandes, 2010b). Thus, the integration of the hyperthermophilic pullulanase in the process may not be straightforward given the delicate balance required between low activity and high stability. A roughly similar pattern regarding kinetics and thermal stability was evidenced by a pullulanase from the hyperthermophilic archaeon Thermococcus sp. HJ21 (Xu et al., 2009). Accordingly, efforts are being made to produce pullulanase variants from hyperthermophylic marine strains that display the same or higher thermal stability, while presenting a more favorable temperature dependent activity profile. The combined features will ease integration with other enzymes for starch processing (Borchert et al., 2011).

\section{GLUCOSIDASES}

$\beta$-Glucosidases (3.2.1.21) are accountable for the hydrolysis of terminal, non-reducing $\beta$-D-glucosyl residues of alkyl and aryl $\beta$-glycosides as well as disaccharides and short chain oligosaccharides, with release of $\beta$-D-glucose residues (Bhatia et al., 2002). $\beta$-Glucosidases can be divided into glycoside hydrolase family 1, GH1, and glycoside hydrolase family 3, GH3, depending on their amino acid sequences. Most of GH1 enzymes display noticeable $\beta$-galactosidase and $\beta$-glucosidase activity, whereas GH3 enzymes display the later activity (Henrissat, 1991). $\beta$ Glucosidases are widely used for the processing of fruit juices, wine and beer, namely aiming to improve organoleptic properties and release aroma and flavor compounds (Günata, 2003; Longo and Sanromán, 2006; Kang et al., 2010; Mojsov, 2013; Trincone, 2013b; Wang et al., 2013).

$\beta$-glucosidases can also be used as additives in cellulose-based feeds for single-stomach animals, viz. chicken or pigs, since they enhance the digestibility of the feed (Zhang et al., 1996); and to increase the content of essential oil content in tea beverages ( $\mathrm{Su}$ et al., 2010) Enzymes sought after for application in biotechnological processes should present high hydrolyzing activity, glucose tolerance, heat and acid resistance, and eventually also transglycosylation activity (Bohlin et al., 2013). Pioneering screening of $\beta$-glucosidases from marine sources that fit in these requirements led to the identification of Thermotoga maritima as the producer of such enzyme (Goyal et al., 2001). After cloning and expressing the enzyme in $E$. coli, the enzyme displayed optimal activity at $85^{\circ} \mathrm{C}$ and $\mathrm{pH}$ 5. Under a more acidic $\mathrm{pH}$ environment, $\mathrm{pH}$ 3 , where the initial activity was $25 \%$ of that observed at $\mathrm{pH} 5$, the temperature optimum decreased to $70^{\circ} \mathrm{C}$. Accordingly, the shift in $\mathrm{pH}$ from 5 to 3 also led to a decrease of the temperature at which the enzyme retained full activity after $30 \mathrm{~min}$ incubation at a given temperature, from $75^{\circ} \mathrm{C}$ to $40^{\circ} \mathrm{C}$. The enzyme also remained stable within a $\mathrm{pH}$ range of 5-9 and activity, based on substrate depletion, was enhanced in the presence of small-chain alcohols, possibly as a result of transglycosylation, up to hexanol. For longer chain alcohols, the impact was negative (Goyal et al., 2001). These features are illustrative of the impact of operational conditions in enzyme performance, yet the overall results clearly hint the potential of the enzyme for practical application. Since Thermotogae species are (hyper)thermophilic 
(Gupta and Bhandari, 2011), it is expected that they may produce further thermostable $\beta$-glucosidases, and have been further screened. Given the difficulties of culturing these strains, cloning and expression in a suitable host is typically performed. Accordingly, T. neopolitana was shown to produce a GH3 thermostable $\beta$-glucosidase (TnBgl3B) particularly fit for synthesis purposes (Turner et al., 2007). Therefore, alongside with a temperature optimum for activity of $90^{\circ} \mathrm{C}$, which roughly matches the unfolding temperature, the enzyme exhibited a synthesis to hydrolysis reaction rate ratio $\left(\mathrm{r}_{\mathrm{s}} / \mathrm{r}_{\mathrm{h}}\right)$ of 4.5 , regarding the production of hexyl glucopyranoside from p-nitrophenyl- $\beta$-Dglucopyranoside (pNPG), in hexanol: water, for a total conversion rate pNPG of $831 \mu \mathrm{mol} \mathrm{min}{ }^{-1} \mathrm{mg}^{-1}$. This ratio peaked at 5.1 at $60^{\circ} \mathrm{C}$, for a total conversion rate of $153 \mu \mathrm{mol} \mathrm{min}{ }^{-1} \mathrm{mg}^{-1}$. The reduced difference in $r_{s} / r_{h}$ suggested that temperature has a mild impact on the competition between water and hexanol as nucleophiles in the reaction. Moreover, the $r_{s} / r_{h}$ values exceeded those reported for several $\beta$-glucosidases, evidencing its adaptation for alcoholysis, which was particularly favored at $16 \%(\mathrm{v} / \mathrm{v})$ water content in hexane:water, hence the potential of this particular enzyme for alkyl glucoside synthesis. On the other hand, it was observed that the $\mathrm{pH}$ optimum shifted from 5.3 to 5.8 when total reaction rate or $r_{s} / r_{h}$, respectively, were considered, suggesting that the ionization state of the enzyme influences its nucleophile specificity. It was later established that these catalytic features were closely related to structural issues (Pozzo et al., 2010). The glucosidase, which had a three-domain structure, quite uncommon for GH3 enzymes, displayed an active site much more accessible to solvent molecules than the corresponding site of structurally homologous enzymes. Simultaneously, and associated with the construction of active site variants through mutation some residues in the active site were identified as critical for substrate recognition and accommodation. Overall the information gathered is likely to provide a more rational basis for the design of reaction systems involving this glucosidase. The trend to produce mutant $\beta$-glucosidases, rather than tapping microbial sources for new enzymes, in the quest for improved catalytic features has gained relevance. Structural analysis was also the methodology used to improve the catalytic efficiency of $\beta$-glucosidase $(\mathrm{TnBgl}$ 1A), also from T. neopolitana, but from GH1, on quercetin conjugates, in order to obtain the aglycone, more active form of the flavonoid as anti-oxidant (Khan et al., 2011). Mutation of residues close to the sugar binding site led to conformational changes in the active site and increased substrate interactions. This enhanced the hydrolytic activity on quercetin-3-glucoside, whereas the wild type (WT) is mostly active on quercetin- 4 'glucoside. Since the two forms of quercetin are the most abundant in the raw material, an efficient process for the production of quercetin aglycone requires hydrolysis of both species. The mutations introduced resulted in minor changes in catalytic efficiency (as $\mathrm{k}_{\mathrm{cat}} / \mathrm{K}_{\mathrm{M}}$ ), transition temperature and stability, as compared to the WT (Khan et al., 2011). Based on the knowledge gathered in this work, namely on structure-activity relation, further mutations of the $\mathrm{TnBgl} 1 \mathrm{~A}$ enzymes were produced, aiming to further increase the yield of alkyl glucosidase in the transglycosylation reaction and bring the process closer to commercial use (Lundemo et al., 2013). Shifting the polar asparagine with non-polar phenylalanine led to a 7 fold increase in $r_{s} / r_{h}$ ratio, allowing for a $57 \%$ yield in hexyl- $\beta$-glucoside from a $34 \mathrm{mM}$ solution of pNPG in about $4 \mathrm{~h}$. A site specific mutation was also recently used to increase the performance of $\beta$-glucosidase $(\mathrm{GH} 1)$ from T. maritima on quercetin-3,4'-glucoside $\left(\mathrm{Q} 3,4^{\prime}\right)$ and on quercetin- $4^{\prime}$-glucoside $\left(\mathrm{Q} 4^{\prime}\right)$. Changing the hydrophobic glycine by the polar threonine at position 224, located in an active site pocket, resulted in an increase in the conversion of both $\mathrm{Q} 4^{\prime}$ and Q3, $4^{\prime}$, observed in 10 min runs, suggesting enhanced interaction with given hydroxyl groups in the quercetin backbone (Figure 1). In the former substrate $100 \%$ conversion of a $0.24 \mathrm{mM}$ solution was observed, against $70 \%$ conversion for the WT; in the later substrate, the conversion was increased by about $30 \%$ as compared to the WT. These results are in accordance with a decrease in $\mathrm{K}_{\mathrm{M}}(0.75$ fold $)$, increase of $\mathrm{k}_{\text {cat }}$ (3.1 fold) and accordingly of increased $\mathrm{k}_{\text {cat }} / \mathrm{K}_{\mathrm{M}}$ (3.1 fold) when the activity of the mutant on Q4'was compared to WT (Sun et al., 2014). Additionally, the mutation slightly increased the optimum temperature for activity, from 90 to $95^{\circ} \mathrm{C}$, but had no significant impact in thermal or pH stability (within 6.5-8.3). Apart from Thermotogae species, production of $\beta$-glucosidases from Martelella mediterranea (Mao et al., 2010) and from Aeromonas sp. HC1le-3 (Huang et al., 2012) after cloning and expression in E. coli has also been recently reported. Some interesting issues were observed: in the former work, the glucosidase purified although grouped into $\mathrm{GH} 3$, based on amino acid sequence, surprisingly displayed hydrolytic activity over p-nitrophenyl- $\beta$-D-galactopyranoside alongside with activity over pNPG (Table 4). Given iths activity over konjac poder, the enzyme can be used in the preparation of oligosaccharides with a prebiotic role (Mikkelson et al., 2013) or in the production of low protein foods with appelaing flavor and propoer texture (Nakaya et al., 2010). The enzyme proved surprisingly stable in alkaline environment, since it retained $80 \%$ of initial activity after 24-h incubation at $\mathrm{pH} 11.0$; and was active at low temperatures, as it exhibited $50 \%$ of activity at $4^{\circ} \mathrm{C}$, a feature that can be particularly useful in industrial processes where low temperatures are required to maintain the flavor of the product (Kumar et al., 2011). The alkali-stable nature of the enzyme was tentatively ascribed to the roughly $2: 1$ ratio of hydrophobic to hydrophilic amino acids residues in the enzyme molecule (Mao et al., 2010). The cold active nature was assigned to the combination of a significant random coil presence (46\%) which makes the molecular structure highly flexible, a pattern enhanced by the presence of aspartic acid, valine, serine, glycine, and alanine around the active site, together with a ratio of asparagines and glycines to arginines and prolines of 1.42 (Mao et al., 2010). These features have been related to the ability of enzymes to adapt to low temperatures (Huston et al., 2004; Bauvois et al., 2008; Helland et al., 2009). This pattern is thus associated with the high flexibility of psycrophilic enzymes, which involves a decrease in weak interactions or the fading of stability factors, leading to improved dynamics of active site residues under low temperatures (Struvay and Feller, 2012). Cold active enzymes present thus appealing features, such as high specific activity, which allows for a lower amount of enzyme required for a given application, as well as its easy inactivation when prolonged enzymatic action becomes unwanted (Trincone, 2011). 
<smiles>O=c1c(O)c(C2=CCCC(O)=C2)oc2cc(O)cc(O)c12</smiles>

Quercetin<smiles>O=C(O)C1C(O)C(O)C(O)C(O)C(O)C1O</smiles>

Quercetin-4'-glucoside<smiles>O=c1c(OC2OC3OC(C(O)C2O)C(O)C(O)C3O)c(-c2cccc(O)c2)oc2cc(O)cc(O)c12</smiles>

Quercetin-3-glucoside

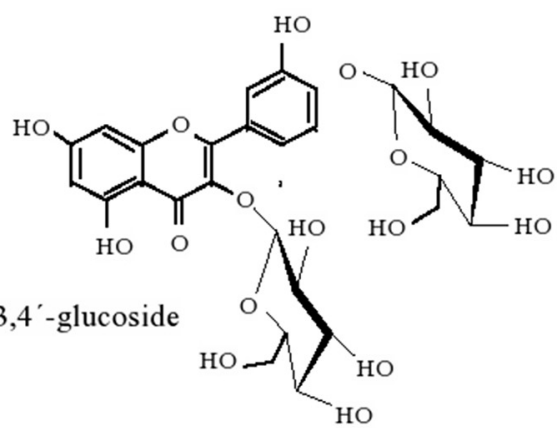

FIGURE 1 | Quercetin and quercetin glucosides resulting of given biotransformations.

The glucosidase (BglA) from Aeromonas sp. HC11e-3 was cloned and expressed in E. coli BL21. Although exhibiting significant sequence similarity (45\%) to the well characterized glucosidase, TnBgl3B, BglA displayed disparate catalytic properties, namely regarding $\mathrm{pH}$ and temperature dependence and substrate specificity (Huang et al., 2012). Thus, BglA proved a relatively acidic enzyme (Table 4). Most notably, BglA evidenced specific aryl-glucosidase activity, one of the few glucosidases of the kind, suggesting its potential for application in fruit juice or wine processing, by promoting the release of flavor reagents and thus enhancing their flavor (Belancic et al., 2003). These particular features, and particularly the ability to withstand the presence of chemical agents, were ascribed to the particular folding of the protein. Tramice and co-workers also reported on the production of a glucosidase from Aplysia fasciata, a gastropod mollusk (Tramice et al., 2011). In this case, the enzyme was identified as an $\alpha$-D-glucosidase (EC 3.2.1.20) which display hydrolytic activity on terminal, non-reducing $(1,4)$-linked $\alpha$-D-glucose residues of glucooligosaccharides, with the release of d-glucose. In the work reported, rather than hydrolysis, polyglycosylation activity of the enzyme was taken advantage of, to synthesize di- to tetrasaccharidic derivatives of (2-hydroxymethyl2,5,7,8-tetramethylchroman-6-ol), with maltose as donor. The most plentiful disaccharide synthesized, of hydrosoluble nature, evidenced significant scavenging properties, and its use as antioxidant within the scope of food industry was hence suggested.

\section{INULINASES}

Inulinases are enzymes with hydrolytic activity over inulin, a polyfructan present in several plants, viz. Jerusalem artichoke and chicory, where fructosyl units are bound together by $\beta$ $(2,1)$ linkages. Total or partial hydrolysis leads to the production of fructose or of fructooligosaccharides, respectively. These are widely used in the food industry, either as sweetener or as prebiotic, respectively (Li et al., 2007; Lima et al., 2011). Inulinases are classified either as endo-inulinases (EC 3.2.1.7) or exoinulinases (EC 3.2.1.80) whether they cleave the inulin chain into smaller oligosaccharides or hydrolyze the terminal fructose from the inulin chain (Basso et al., 2010). Their application for inulin hydrolysis is illustrated in Figure 2.

Reaction can be performed in a temperature range within $40-75$, but most commonly hydrolysis is carried out at $45-55^{\circ} \mathrm{C}$ (Kerkhoffs, 1981; Uchiyama et al., 2005; Ricca et al., 2007). Given such pattern, thermostable inulinases are looked after, although turning to the marine environment to perform such quest is a recent approach. Pioneering work on this was carried out by Gao and co-workers, who, after screening over 400 yeast strains were able to identify four producers of extracellular inulinases displaying different product profiles (Table 5) (Gao et al., 2007). Accordingly, Pichia guilliermondii OUC1 could be used for the production of ultra-high fructose syrups, whereas Yarrowia lipolytica OUC2 could be used for the production of inulooligosaccharides (Guo, 2009; Lima et al., 2011). The opti$\mathrm{mal} \mathrm{pH}$ and temperature of the inulinases from these marine yeasts are clearly within the typical range of those parameters for microbial inulinases. Thus, and safe for very few exceptions, optimum temperature lies within $45-55^{\circ} \mathrm{C}$ and $\mathrm{pH}$ within 4.0-6.0 (Kango and Jain, 2011). On the other hand, an extracellular inulinase from Marinimicrobium sp. LS-A18 exhibited an alkali-tolerant nature, since activity peaked at $\mathrm{pH}$ 9.0, a 
Table 4 | Effect of operational conditions in the performance of some recombinant $\beta$-glucosidases.

\begin{tabular}{|c|c|c|c|c|}
\hline Source & Enzyme & $\begin{array}{l}\mathrm{pH}(-) \text { and temperature optimum } \\
\left({ }^{\circ} \mathrm{C}\right) \text {, activity and stability }\end{array}$ & Comments & References \\
\hline $\begin{array}{l}\text { Martelella } \\
\text { mediterranea } \\
2928 \text { gluc3m gene } \\
\text { cloned into E. coli }\end{array}$ & $\beta$-glucosidase & $\begin{array}{l}\text { 8.0; } 45 . \text { High activity in } 7.0<\mathrm{pH}< \\
8.0 \text { and } 30<T<60 \text {. High stability } \\
\text { in } 8.0<\mathrm{pH}<11.0 \text { and } 0<T<40\end{array}$ & $\begin{array}{l}\text { Activity stimulated by } \mathrm{NH}_{4}^{+}, \mathrm{K}^{+}, \mathrm{Na}^{+}(1 \mathrm{mM} \text {, } \\
\text { each), and by EDTA and } \beta \text {-mercaptoethanol } \\
(1 \% \text {, each); unaffected by SDS }(1 \mathrm{mM}) ; \text { and } \\
\text { inhibiton by } \mathrm{Ca}^{2+}, \mathrm{Cu}^{2+}, \mathrm{Co}^{2+}, \mathrm{Hg}^{2+}, \mathrm{Mg}^{2+}, \\
\mathrm{Mn}^{2+}, \mathrm{Pb}^{2+} \text { and } \mathrm{Zn}^{2+}(1 \mathrm{mM} \text {, each) } \\
\text { Activity }(\mathrm{U} / \mathrm{mg}) \text { : high over pNPGal }(200 \mathrm{U} / \mathrm{mg}) \\
\text { and pNPG* (196), mild over pNPX** (36) and } \\
\text { konjac powder (16); residual over salicin (9), } \\
\mathrm{CMC}^{+}(4) \text { and locust bean gum (1); nihil over } \\
\text { glucan, laminarin and xylan }\end{array}$ & Mao et al., 2010 \\
\hline $\begin{array}{l}\text { Aeromonas sp. } \\
\text { HC11e-3 gene } \\
\text { cloned into E. coli }\end{array}$ & $\begin{array}{l}\beta \text { - glucosidase } \\
\text { (Bg|A) }\end{array}$ & $\begin{array}{l}\text { 6.0; 55. High activity in } 5.0<\mathrm{pH}< \\
6.0 \text { and } 50<T<60 \text {. High stability } \\
\text { in } 5.0<\mathrm{pH}<6.5 \text { and } 10<T<30\end{array}$ & $\begin{array}{l}\text { Activity stimulated by } \mathrm{Ba}^{2+}, \mathrm{Ca}^{2+}, \mathrm{NH}_{4}^{+}, \mathrm{Mn}^{2+}, \\
\mathrm{Sr}^{2+}, \mathrm{Zn}^{2+} \text { and } \mathrm{Pb}^{2}(1 \mathrm{mM} \text {, each); unaffected } \\
\text { by } \mathrm{Ni}^{+} \text {and } \mathrm{Co}^{2+}(1 \mathrm{mM} \text {, each); inhibited by } \\
\mathrm{Cu}^{2+}, \mathrm{Hg}^{2+}, \mathrm{EDTA}(1 \mathrm{mM} \text {, each), dithiothreitol } \\
\text { and } \mathrm{SDS}(1 \% \text {, each) } \\
\text { Activity }(\mathrm{U} / \mathrm{mg}) \text { : high over esculin (278), arbutin } \\
\text { (118) and pNPG** (98); residual (under } 0.85) \\
\text { over pNPX***, pNPGal*, salicin, } \mathrm{CMC}^{+}, \text {locust } \\
\text { bean gum, laminarin and xylan }\end{array}$ & Huang et al., 2012 \\
\hline
\end{tabular}

${ }^{*}$ pNPGal, p-nitrophenyl- $\beta$-D-galactoside; ${ }^{* *} P$ npg, p-nitrophenyl- $\beta$-D-glucopyranoside; ${ }^{* *} p N P X, p$-nitrophenyl- $\beta$-D-xyloside; CMC, carboxymethyl celulose. Activity unit $U)$ defined as the amount of enzyme required for the hydrolysis of $1 \mu \mathrm{mol}$ of substrate per minute.

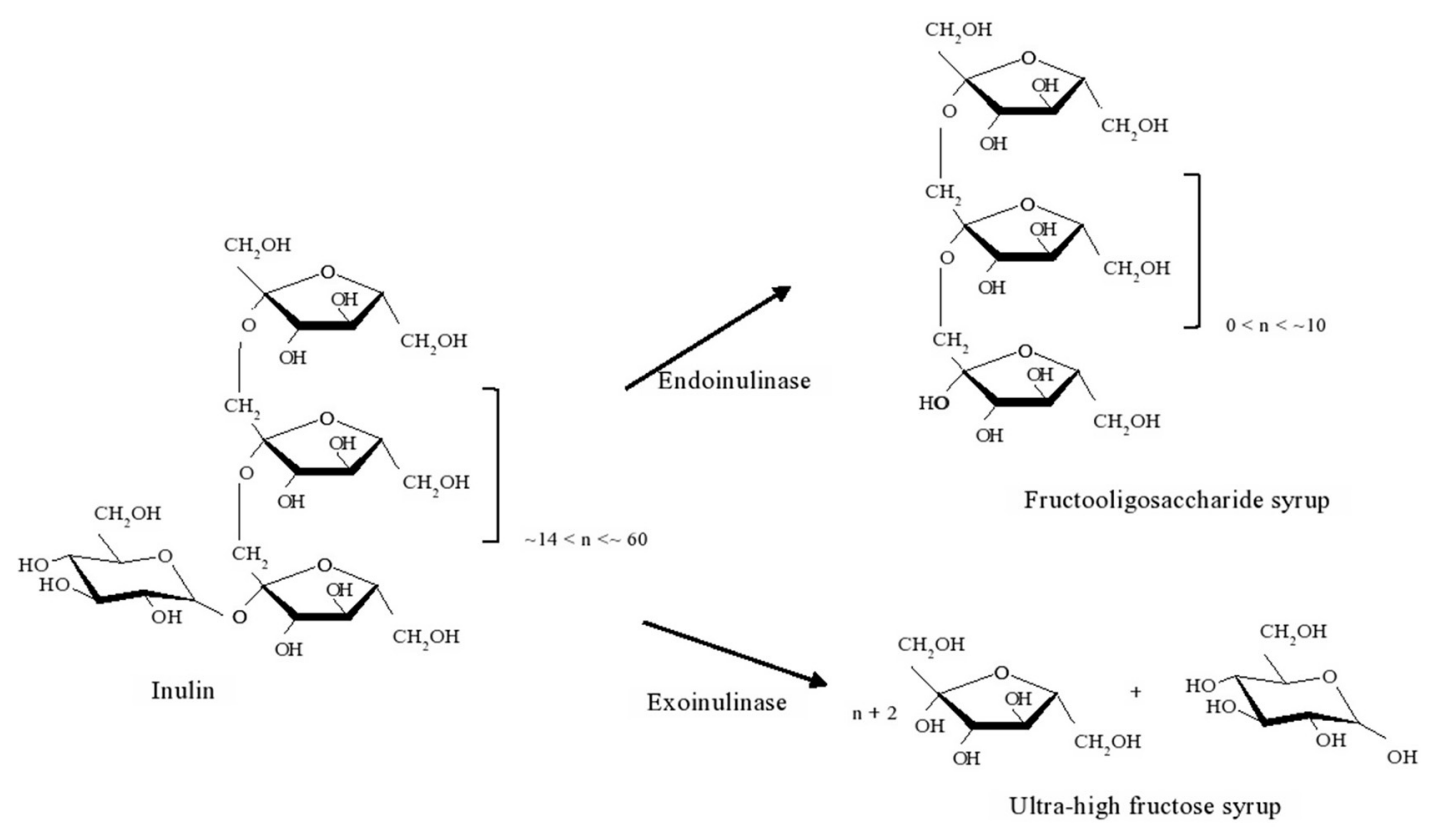

FIGURE 2 | Schematics of the action of endoinulase or exoinulinase on inulin, to produce fructooligosaccharide syrup or ultra-high fructose syrup respectively.

quite uncommon feature for inulinases. The inulinase was also halo-tolerant, for although the maximum activity was observed under $0.5 \%(\mathrm{w} / \mathrm{V}) \mathrm{NaCl}$, it retained about $60 \%$ of that activity under $20 \% \mathrm{NaCl}$. Regarding temperature, the enzyme displayed a more traditional nature, for activity peaked at $55^{\circ} \mathrm{C}$. Inulin hydrolysis can thus be performed in such alkaline environment, since unwanted color formation was ruled out at this temperature, only at $65^{\circ} \mathrm{C}$ and $\mathrm{pH}$ at least 10 was a slight yellow color observed after $4 \mathrm{~h}$ of operation (Li et al., 2012). Alkalitolerance ( $\mathrm{pH}$ optimum of 8.0, and activity within $\mathrm{pH} 5.0-11.0$ ) 
Table 5 | Catalytic behavior of inulinases from marine yeasts (Gao et al., 2007).

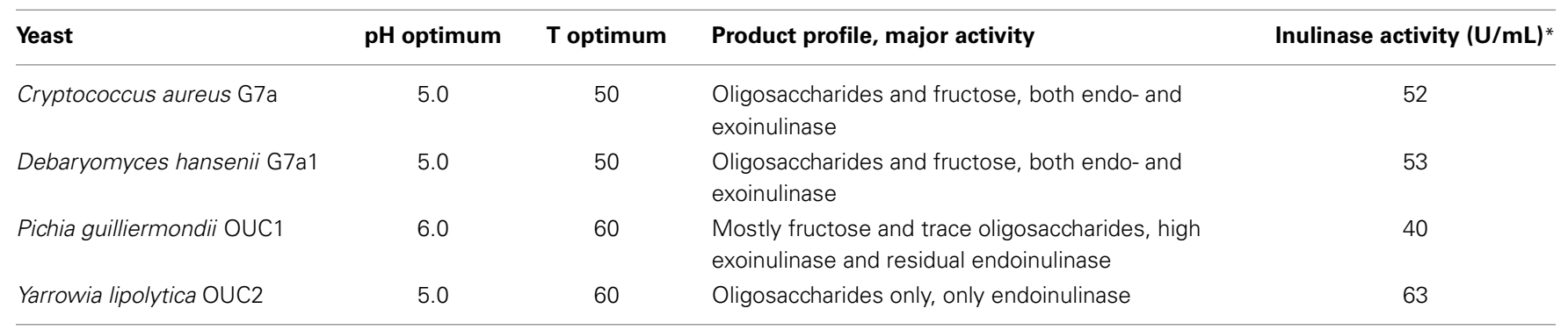

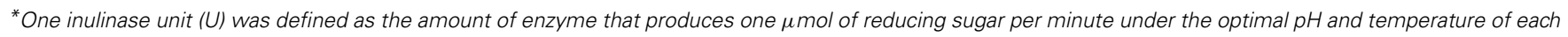
enzyme.

and thermostable nature (temperature optimum of $60^{\circ} \mathrm{C}$ ) was also displayed by an extracellular inulinase from Nocardiopsis sp. DN-K15 (Lu et al., 2014). Both of these two enzymes displayed exo-inulinase activity, thus could be considered for the production of ultra-high fructose syrups. Bacillus cereus MU-31 was also identified as a producer of an extracellular exo-inulinase. However, safe for establishing that $\mathrm{Hg}^{2+}$ and $\mathrm{Pb}^{2+}$ severely inhibited enzyme activity, whereas $\mathrm{Mg}^{2+}$ slightly stimulated it, no detailed characterization on kinetics and stability was provided (Meenakshi et al., 2013).

\section{LIPASES/ESTERASES}

Lipases and esterases (EC 3.1.1.X) are carboxyl hydrolases able to cleave and form ester bonds. Esterases and lipases and widely used in the food industry, viz. for improving the quality of bread through changes in flour lipids; for flavor enhancement of butter, cheese, and margarine; in the production of crackers, pasta and similar; for degumming of vegetable oils; in the synthesis of structured lipids for infant formula and nutraceutical; for increasing the titer of polyunsaturated fatty acids in vegetable oils; for improving the digestability of natural lipids (Panda and Gowrishankar, 2005; Aravindan et al., 2007; Visser et al., 2012; Ferreira-Dias et al., 2013). Lipases used to be differentiated from esterases since the former display interfacial activation. Thus, as a result of the conformation and surface polarity, in the presence of a hydrophobic surface a dramatic increase in catalytic activity is observed. However, as it was noticed that some lipases did not exhibit this behavior, or only displayed interfacial activation for some specific substrates, other criteria were looked for. The most acknowledged assumes that lipases promote the hydrolysis (and synthesis) of ester bonds with long chain fatty acids (C10 and longer), whereas esterases prefer sshorter chain fatty acids (Jaeger et al., 1999; Paravidino et al., 2012). These carboxyl hydrolases may be required to operate in demanding environments or specific activities may be targeted, in either case paving the way for tapping marine sources, namely through the construction of metagenomic libraries (Jeon et al., 2011). Through this strategy, Peng and co-workers were able to isolate an alkalinestable lipase and express it in E. coli (Peng et al., 2014). The lipase was quite active within $\mathrm{pH} 7$ to 11 and its lipolytic activity increased steadily up to $50^{\circ} \mathrm{C}$ to decrease sharply up to $60^{\circ} \mathrm{C}$, while retaining full activity after incubation at $30^{\circ} \mathrm{C}$ for 3.5 days. The lipase was effectively used for the production myristic $\left(\mathrm{C}_{14}\right)$ and palmitic $\left(\mathrm{C}_{16}\right)$ acids from butter milkfat. Those two acids are FDA approved food additives that convey a unique flavor to dairy products, yet their production has been largely overlooked since most works focus in the production of short-chain acids (Peng et al., 2014). Lipases from marine sources have also been used for the hydrolysis of mono- and di-acyl glycerols, a set-up that can be used in the production of food emulsifiers. In particular, Yuan and co-workers identified a cold-active lipase from Janibacter sp. strain HTCC2649 with $s n-1 / 3$ specificity toward mono- and diacylglycerols, one of the few, if not only so far, lipase from marine bacteria with such preference (Yuan et al., 2014). The lipase, with p-nitrophenyl caproate $\left(\mathrm{C}_{10}\right)$ as preferred substrate, was active between 5 and $30^{\circ} \mathrm{C}$ and fully stable for $3 \mathrm{~h}$ under up to $30^{\circ} \mathrm{C}$, although activity and stability sharply decayed above this temperature. Moreover, it remains active and stable within $\mathrm{pH}$ of 6.0-11.0 and was insensitive to several commonly used cations, although strongly inhibited by the chelating EDTA and by different types of surfactants. The later was suggested to reflect the impact of negative or positive charges and of hydrophiliclipophilic balance on enzyme activity (Yuan et al., 2014). The marine fungus A. sydowii was also identified as a producer of extracellular lipase and the operational conditions that allowed for optimized production were established. The strain is available from a culture collection, thus further developments on enzyme characterization and application can be expected (Bindiya and Ramana, 2012). Esterases from marine sources have been also been identified as summarized in Table 6. One such esterase, belonging to the hormone-sensitive lipase (HSL) family, was very recently isolated from a metagenomic library containing a little over 10,500 fosmid clones from a surface sediment from the South China Sea (Li et al., 2014). This particular E25 enzyme was shown to require dimerization for catalytic activity to be displayed, unike other HSLs. However, other enzyes from the same GTSAG motif subfamily as E25 may display the same dimerization patern. Thus, dimerization allowed for the catalytic residue Asp282 to present the adequate orientation. Dimerization involved the catalytic triad, composed of residues Ser186, and His312, in addition to residue Asp282, and a CAP domain. This domain is mainly composed of two N-terminal $\alpha$-helices, and participates in substrate binding. The dimer is mostly stabilized by hydrogen bonds and salt bridges formed by hydrophilic residues. E25 proved to be a mesophilic, halotolerant and slightly alkaline esterase, similar to other enzymes from the same GTSAG subfamily (Jeon et al., 
Table 6 | Some recently identified esterases from marine sources.

\begin{tabular}{|c|c|c|c|c|}
\hline Source & Enzyme & $\begin{array}{l}\text { pH }(-) \text { and temperature optima } \\
\left({ }^{\circ} \mathrm{C}\right) \text { and activity }\end{array}$ & Comments & References \\
\hline $\begin{array}{l}\text { Metagenomic library } \\
\text { from South China } \\
\text { Sea }\end{array}$ & Esterase A & $\begin{array}{l}\text { 6.5; 45. High activity in } 5.5<\mathrm{pH}< \\
8.0 \text { and } 35<T<50\end{array}$ & $\begin{array}{l}\text { Active for } \mathrm{p}-\mathrm{NP}^{*} \text { even numbered fatty acid esters } \\
\text { from } \mathrm{C}_{4} \text { to } \mathrm{C}_{10} \text {, particularly } \mathrm{C}_{6} \text {. Classic catalytic triad } \\
\text { composed of } \mathrm{S} 146, \mathrm{D} 222 \text {, and } \mathrm{H} 255 \\
\text { Activity stimulated by various water miscible organic } \\
\text { solvents ( } 15 \% \text { ) and by } \mathrm{Mg}^{2+}, \mathrm{Mn}^{2+}, \mathrm{Ca}^{2+}, \mathrm{Co}^{2+} \text { and } \\
\text { by EDTA (each } 10 \mathrm{mM}) \text {. Inhibiton by } \mathrm{Fe}^{2+}, \mathrm{Fe}^{3+} \text { and } \\
\mathrm{Zn}^{2+}(10 \mathrm{mM} \text {, each) and various water miscible } \\
\text { organic solvents }(30 \%) \text { safe for DMSO** }\end{array}$ & Chu et al., 2008 \\
\hline
\end{tabular}

\begin{tabular}{ll}
\hline Esterase B & $7.5 ; 45$. High activity in $5.5<\mathrm{pH}<$ \\
& 8.0 and $35<T<50$
\end{tabular}

Active for $\mathrm{p}-\mathrm{NP}$ even numbered fatty acid esters

Chu et al., 2008

from $\mathrm{C}_{4}$ to $\mathrm{C}_{10}$, particularly $\mathrm{C}_{4}$. Catalytic triad

composed of S149-E243-H273

Activity stimulated by various water miscible organic

solvents (15\% and $30 \%)$ and by $\mathrm{Co}^{2+}$; inhibited by

$\mathrm{Mg}^{2+}, \mathrm{Cu}^{2+}, \mathrm{Zn}^{2+}, \mathrm{Mn}^{2+}, \mathrm{Fe}^{2+}$ and $\mathrm{Fe}^{3+}(10 \mathrm{mM}$,

each)

\begin{tabular}{lll}
\hline Metagenomic library & Esterase 6 & 7.5; 20. High activity in $6.0<\mathrm{pH}<$ \\
from deep-sea & & 8.0 and $15<T<45$
\end{tabular}

Active for p-NP even numbered fatty acid esters

from $C_{4}$ to $C_{12}$, particularly $C_{4}$. Catalytic triad

composed of S144, E238, and H268

Stable up to $30^{\circ} \mathrm{C}$. Activity stimulated by $\mathrm{Mg}^{2+}$,

$\mathrm{Mn}^{2+}$, EDTA Tween 20 and Tween 80 (1\%); inhibited

by $\mathrm{Ba}^{2+}, \mathrm{Ca}^{2+}, \mathrm{Co}^{2+}, \mathrm{Cu}^{2+}, \mathrm{Ni}^{2+}, \mathrm{Sr}^{2+}, \mathrm{Zn}^{2+}$ and by

various water miscible organic solvents

\begin{tabular}{ll}
\hline Vibrio fischeri $\quad$ Esterase & $\begin{array}{l}7.5 ; 30 . \text { High activity in } 6.0<\mathrm{pH}< \\
8.0 \text { and } 25<T<40\end{array}$
\end{tabular}

Pelagibacterium

halotolerans B2T

Esterase PE10 7.5; 45. High activity in $6.0<\mathrm{pH}<$ 8.5 and $35<T<55$

Activity stimulated by $\mathrm{SDS}^{* * *}$; inhibited by $\mathrm{Ba}^{2+}$, $\mathrm{Ca}^{2+}, \mathrm{Cu}^{2+}, \mathrm{Fe}^{2+}, \mathrm{K}^{+}, \mathrm{Mg}^{2+}, \mathrm{Mn}^{2+}, \mathrm{Na}^{+}, \mathrm{Sr}^{2+}$, and EDTA
Mohankumar

and Ranjitha,

2010

The enzyme was cloned and overexpressed in E. coli Jiang et al.,

Rosetta. High active for $\mathrm{p}-\mathrm{NP}^{*} \mathrm{C}_{2}$ and $\mathrm{C}_{4}$; residual $2012 \mathrm{~b}$ activity under $20 \%$ and gradually decreasing for $\mathrm{C}_{6}$ to $\mathrm{C}_{16}$. Active for $0 \mathrm{M}<\mathrm{NaCl}<4 \mathrm{M}$, peaking at $3 \mathrm{M}$ Activity was inhibited by several water miscible solvents (15\%), by Triton X-100 and by SDS*** $(1 \%$, each). Activity was stimulated by $\mathrm{Ba}^{2+}$ and $\mathrm{Mn}^{2+}$ (10 mM, each); unaffected by $\mathrm{Ca}^{2+}(10 \mathrm{mM})$; and inhibited by $\mathrm{Ba}^{2+}$ and $\mathrm{Mn}^{2+}\left(5 \mathrm{mM}\right.$, each), $\mathrm{Ca}^{2+}$ $(5 \mathrm{mM})$, EDTA $(10 \mathrm{mM})$, and $\mathrm{Co}^{2+}, \mathrm{Cu}^{2+}, \mathrm{Mg}^{2+}, \mathrm{Ni}^{2+}$, $\mathrm{Sr}^{2+}$ and $\mathrm{Zn}^{2+}$ (both at $5 \mathrm{mM}$ or $10 \mathrm{mM}$, each)

\begin{tabular}{lll}
\hline Metagenome library & Esterase E25 & $8.5 ; 50^{\circ} \mathrm{C}$. High activity in $8.0<\mathrm{pH}$ \\
from sediments from & $<9.0$ and $30<T<60$. High \\
South China sea & stability in $6.0<\mathrm{pH}<10.0$ and $0<$ \\
& $T<50$
\end{tabular}

Activity peaks for $1 \mathrm{M} \mathrm{NaCl}$ and remains very high up Li et al., 2014 to $3.0 \mathrm{M} \mathrm{NaCl}$. Activity was stimulated by EDTA and

$\mathrm{Mn}^{2+}\left(10 \mathrm{mM}\right.$, each); unaffected by $\mathrm{Co}^{+}, \mathrm{K}^{+}, \mathrm{EDTA}$

(1 $\mathrm{mM}$, each), $\mathrm{Ca}^{2+}$ and $\mathrm{Mg}^{2+}(10 \mathrm{mM}$, each),

inhibited by $\mathrm{Ca}^{2+}, \mathrm{Mg}^{2+}$, and EDTA (1 $\mathrm{mM}$, each),

$\mathrm{Mn}^{2+}$ and $\mathrm{K}^{+}(10 \mathrm{mM}), \mathrm{Li}^{+}, \mathrm{Cu}^{2+}, \mathrm{Fe}^{2+}, \mathrm{Ni}^{2+}$,

$\mathrm{Zn}^{2+}(1$ and $10 \mathrm{mM}$, each)

${ }^{*} p$-NP, p-Nitrophenyl; ${ }^{* *} D M S O$, dimethyl sulfoxide; ${ }^{* * *} S D S$, sodium dodecylsulfate.

2012; Li et al., 2014). Hydrolytic activity of E25 was assessed using as substrates p-nitrophenyl esters from C2 to C16. The preferred substrate was the $\mathrm{C} 4$ ester (100\% relative activity), with the relative activity gradually decreasing to reach $20 \%$ for $\mathrm{C} 10$ ester and become residual for C14 and C6 esters. This pattern shighlight the esterase nature of E25 (Jaeger et al., 1999; Li et al., 2014)

\section{PROTEASES}

Proteases hydrolyze peptide bonds in proteins and polypeptides. Proteases display a wide diversity of mechanisms of action, yet typically the active sites of protease are surrounded in either one or both sides by at least one subsite that can accommodate the side chain of specific single amino acid residue from the substrate (Ward et al., 2009). They are typically produced in bulk 
amounts and used as relatively crude preparations in the food industry, with application in a wide array of processes. These span over a wide range of operational conditions (viz. temperature, $\mathrm{pH}$, osmolarity) and may or may not require a high specificity in enzyme action (Sawant and Nagendran, 2014). The use of proteases over food proteins intends to accomplish given goals, such as: improved digestibility and or solubility; modified functionality, viz. emulsification, fat- or water-binding, foaming and gel strengthening, whipping properties; improved or modified flavor; and improved processing. Representative examples of such applications are given in Table 7. Some recently isolated proteases from marine sources may be used in some of these processes. An alkaline protease from the marine Aureobasidium pullulans HN23 was cloned and expressed in Yarrowia lipolytica and used for the production of bioactive peptides in what was claimed to be a pioneer work. These nutraceuticals are used in the promotion of human health. In this particular work, angiotensin-converting

\section{Table 7 | Examples of protease application in food industry}

(Claverie-Martìn and Vega-Hernàndez, 2007; Korhonen, 2009; Zhao

et al., 2011; Miguel et al., 2013; Steen and Arnosti, 2013).

\begin{tabular}{ll}
\hline Industry & Comments \\
\hline Baking & $\begin{array}{l}\text { Dough uniformity and decreased dough } \\
\text { consistency. Partial hydrolysis of gluten, } \\
\text { control of bread texture and flavor }\end{array}$ \\
\hline Brewing & $\begin{array}{l}\text { Extraction of proteins from malt and barley so } \\
\text { that the required nitrogen is provided to yeast }\end{array}$ \\
\hline Dairy & $\begin{array}{l}\text { Milk coagulation mostly for cheese making, } \\
\text { through aspartic proteases (chymosin and } \\
\text { pepsin) Proteolytic and (low) thermal stability } \\
\text { akin to that of rennet are looked after. Ripening } \\
\text { and flavor development. Fish pepsin has } \\
\text { shown promising results for cheese } \\
\text { production, but commercial scale process has } \\
\text { not yet been claimed }\end{array}$
\end{tabular}

Fish and seafood

Production of fish hydrolyzates. Fish pepsin has been used in the production of fish silage Deproteinization of crustacean waste for the production of chitin. Ease the removal of skin from fish. Scale removal. Fish pepsin can be utilized in gentle processing of some fish raw materials. Cod pepsin has been used for caviar production, for deskinning of herring and has been commercialized for descaling of fish

Fruit juices and soft Reduce turbidity through protein hydrolysis, drinks fortification of fruit juices and soft drinks

Functional foods and Production of bioactive peptides

nutraceuticals

\begin{tabular}{ll}
\hline Meat & Tenderization and flavor development \\
\hline Soy & $\begin{array}{l}\text { Hydrolysis of soy bean proteins for soy sauce } \\
\text { manufacturing }\end{array}$
\end{tabular}

enzyme (ACE) inhibitory activity, which provide antihypertensive effects without side effects and anti-oxidant activity, was displayed by the products of the reaction (Ni et al., 2009). Within the group of amino peptidases, which are often used in the food industry for debittering and enhancing the functional properties of protein based products and for cheese flavoring, one of these enzymes was isolated from a marine A. flavus (Sriram et al., 2012). The enzyme and characterized, once fermentation conditions that optimized the envisaged activity production were identified. The protease with leucyl amino peptidase activity, thus cleaving terminal protein or peptide residues, has $120 \mathrm{kDa}$, was quite active in neutral to slightly alkaline environment, with activity peaking at $\mathrm{pH} 7.0$, and within $35-55^{\circ} \mathrm{C}$. Psychrophilic leucyl aminopeptidases, alongside with chymotrypsin and trypsin activities have also been identified within the spectrum of extracellular enzymes from heterotrophic microorganism in the waters of an Arctic fjord (Steen and Arnosti, 2013). Chymotrypsin and trypsin are serine proteases typically isolated from mammalian sources (Klotz et al., 2010). The former has specific hydrolytic activity toward peptides of amino acids with aromatic residues, and is used for diverse applications, such as deallegenizing milk hydrolyzates or processing fish sauce. The later typical cleaves peptides on the C-terminal side of lysine and arginine amino acid residues and can be used to predigest food in baby food. Moreover, chymotrypsin and trypsin are part of a blend of proteases used to produce seafood flavors for the food industry (Benediktsson and Bjarnason, 2001; Gudmundsdottir, 2007; Klomklao, 2008). A relatively thermostable protease has also been pooled from a marine microorganism belonging to the genus Marinobacter, and was isolated from the Indian Ocean, but no further details on its specificity were provided (Fulzele et al., 2011). Proteases from marine sources with applications in meat processing have also been identified. Tenderization of meat is largely looked after, as tenderness is a key sensory quality of meat. Tenderness is largely influenced by collagen and by elastin, therefore these structural proteins are promising targets for enzyme action (Takagi et al., 1992; Gelse et al., 2003; Bekhit et al., 2013). Most of the enzymes active over those proteins currently considered or used have either mesophilic or thermophilic nature (Zhao et al., 2012a; Bekhit et al., 2013). This is ill-suited for meat tenderization since this is often carried out at room temperature (Zhao et al., 2012a). Cold adapted enzymes can thus be advantageously used for meat tenderization. Such is the nature of protease MCP-01, an abundant extracellular serine protease produced by the deep-sea psychrophilic Pseudoalteromonas sp. SM9913. The activity of the enzyme peaked at low temperatures $\left(25-35^{\circ} \mathrm{C}\right.$, depending on the substrate used), and was active down to $0^{\circ} \mathrm{C}$, while being deactivated at $40^{\circ} \mathrm{C}$, due to autolysis (Chen et al., 2003, 2007a,b). The later feature avoids the risk of over tenderization during/after cooking. This collagenase proved effective in the tenderization of beef meat at $4^{\circ} \mathrm{C}$, since it reduced the beef meat shear force by up to $23 \%$, where it proved as effective as bromelain, a well disseminated meat tenderizer (Zhao et al., 2012a). In addition, moisture preservation was much more effective (3-4 fold) in beef meat processed with MCP-01, than in beef meat processed with bromelain or with papain, also a popular meat tenderizer. The more effective moisture conservation of the meat processed with MCP-01 
resulted in fresher color and a better appearance than that of the remaining processed meats. Incubation of beef meat with MCP01 also resulted in a increase by $92 \%$ of the relative myofibrillar fragmentation index (an indicator that correlates with met tenderization), as compared to the control. Oppositely, the relative myofibrillar fragmentation index of beef meat processed with bromelain only increased by $54 \% \mathrm{~m}$, and it remained unaltered when papain was used. MCP-01 also displayed a higher selectivity toward collagen and in the degradation of myofibrillar proteins, when compared with bromelain and papain. The later reduces the risk of extensive degradation of the meat structure that can result in an undesirable texture (Zhao et al., 2012a). The mechanism of collagen degradation is quite complex and along with the use of MCP-01 (Ran et al., 2013), other collagenase from a deep sea source, Myroides profundi D25, was recently isolated and used to further clarify the mechanism of collagen degradation (Ran et al., 2014). Elucidation of elastin degradation has also been the focus of research, where the use of marine enzymes was involved (Zhao et al., 2012b). In this later work, a pseudoalterin secreted by Pseudoalteromonas sp. CF6-2 from deep-sea sediment was purified and characterized. The pseudoalterin was active at $25^{\circ} \mathrm{C}$ and slightly alkaline $\mathrm{pH}(9.0)$. When bovine elastin was used as substrate the enzyme was shown the break cross-links at structural level, which resulted in the release of filaments, droplets, and spherules from elastic fibers (Zhao et al., 2012b). In the overall, these efforts are expected to result in more efficient processes for meat tenderization.

\section{PHYTASE}

Phytases are able to break down phytic acid, indigestible to nonruminants, therefore making available phosphorus, as well as calcium and other nutrients stored in plants as phytate. Exogenous supplementation of phytase has thus emerged as an efficient way to improve human and animal diets and improve digestion in alimentary tract. This field of research is relatively recent, so there is a clear interest in identifying new effective phytases (Afinah et al., 2010; Mittal et al., 2013). Accordingly, the marine yeast Kodamea ohmeri BG3 was shown to display significant extracellular phytase activity and optimal conditions for microbial production were established. Phytate hydrolysis activity peaked at $\mathrm{pH} 5.0$ and $65^{\circ} \mathrm{C}$, yet the enzyme exhibited significant activity, at least about $50 \%$ of the maximum, within 35 and $70^{\circ} \mathrm{C}$, after which activity decreased sharply. On the other hand, activity strongly depended on $\mathrm{pH}$ since it increased sharply from 3.0, where residual activity was observed, to 5.0, and again decreased sharply to 7.0, where roughly no activity was observed. Roughly full hydrolysis $5.0 \mathrm{mM}$ sodium phytate was observed after $3 \mathrm{~h}$ of incubation at $65^{\circ} \mathrm{C}$ and $\mathrm{pH} 5.0$, although there was no evidence of phytate dephosphorylation (Li et al., 2008).

\section{TANNASE}

Tannases (EC 3.1.1.20) hydrolyze the ester and depside linkages of tannic acid, yielding glucose and gallic acid. It is mostly used for preparing gallic acid, which is used in the preparation of the anti-oxidant propyl gallate; producing coffee flavored soft drinks and instant tea; for the clarification of fruit juice and bear; and for food detannification (Aguilar and Gutierrez-Sanchez, 2001; Molkabadi et al., 2013). Several tannases produced from marine sources have been identified, as summarized in Table 8.

\section{XYLANASES}

Xylanase is a hydrolytic enzyme that degrades xylan, the second most abundant polysaccharide in nature, to xylooligosaccharides,

Table 9 | The xylanolytic enzyme complex (Beg et al., 2001; Harris and Ramalingam, 2010).

\begin{tabular}{|c|c|}
\hline Enzyme & Action \\
\hline $\begin{array}{l}\text { Xylanase (endo-1, } \\
\text { 4- } \beta \text {-d-xylanohydrolase) EC 3.2.1.8 }\end{array}$ & $\begin{array}{l}\text { Hydrolysis of internal glycosidic } \\
\text { bonds within the xylan backbone }\end{array}$ \\
\hline $\begin{array}{l}\text { Arabinofuranosidase, exo-action EC } \\
\text { 3.2.1.55, endo-action EC 3.2.1.99 }\end{array}$ & $\begin{array}{l}\text { Hydrolysis of arabinose residues } \\
\text { from xylosyl units }\end{array}$ \\
\hline$\alpha$-Glucuronidase, EC 3.2.1.131 & $\begin{array}{l}\text { Hydrolysis of glucuronic acid } \\
\text { side-chains from xylosyl units }\end{array}$ \\
\hline Xylan esterase, EC 3.1.1.6 & $\begin{array}{l}\text { Releases acetate groupxylose } \\
\text { residues in acetylated xylans }\end{array}$ \\
\hline$\beta$-Xylosidase, EC 3.2.1.37 & Hydrolysis of xylobiose to xylose \\
\hline
\end{tabular}

Table 8 | Tannases from marine sources. Recent examples.

\begin{tabular}{|c|c|c|c|}
\hline Microbial source & Optimal pH and $\mathrm{T}\left({ }^{\circ} \mathrm{C}\right)$ & Other comments & References \\
\hline $\begin{array}{l}\text { Aspergillus awamori } \\
\text { BTMFW032 }\end{array}$ & 2.0 and $8.0 ; 30$ & $\begin{array}{l}\text { The acidophilic enzyme had two } \mathrm{pH} \text { optima but was unstable at pH } 8.0 \text {. } \\
\text { The enzyme displayed activity within } 5 \text { to } 80^{\circ} \mathrm{C} \text {. Maximal affinity was } \\
\text { observed for methyl gallate }\end{array}$ & Beena et al., 2010 \\
\hline
\end{tabular}

Application for the synthesis of propyl gallate by direct transesterification of tannic acid in the presence of n-propanol. A low conversion of tannic acid $(3.2 \%)$ was observed but conditions were not optimal. The tannase was also used for tea cream solubilization, where $60.0 \%$ of cream $(10 \mathrm{~mL}$ of a brew obtained from $8 \mathrm{~g}$ of tea) was solubilized by $1 \mathrm{~mL}$ of purified enzyme within $1 \mathrm{~h}$, under non-optimized conditions

$\begin{array}{ll}\begin{array}{l}\text { Phormidium } \\ \text { valderianum }\end{array} & \text { Fot determined } \\ \text { BDU140441 } & \begin{array}{l}\text { Synergy between tannase, polyphenol oxidase and esterases for the } \\ \text { degradation of tannic acid }\end{array}\end{array}$


xylobiose and xylose (Beg et al., 2001; Sharma and Kumar, 2013; Singh et al., 2014). The full degradation of xylan into its constitutive sugars requires the cooperative action of a set of hydrolytic enzymes, as summarized in Table 9 (Beg et al., 2001; Harris and Ramalingam, 2010).

Xylanases have found application in the food and feed industries as recently reviewed. Some major outcomes of such applications include: clarification of fruit juices; the decreased viscosity improves filterability of the juice liquefaction of fruits and vegetables; maceration of fruits and vegetables; improved extraction of fermentable sugars from barley, helpful for production of beer and processing of animal feed; improved elasticity of gluten, enhancing handling and increasing stability of the dough in the baking industry; increase in bread volumes, improved absorption/redistribution of water, finer and more uniform crumbs; higher content of arabinoxylooligosaccharides in bread with a positive effect in health health; lighter cream crackers lighter, improved texture, palatability and uniformity of wafers; and improved digestibility of animal feeds (Harris and Ramalingam, 2010; Sharma and Kumar, 2013).

The study of marine xylanases has been rather overlooked, as compared to their terrestrial counterparts, yet some recent reports are sugestive of a turning in this trend. One example of this pattern was the use of the thermostable xylanase B from Thermotoga maritima in the production of frozen partially baked bread (Jiang et al., 2008). The addition of the xylanase to wheat flour dough resulted in softer bread, with higher volume. Crumb firmness decreased during storage, concomitant with anti-stalling effect. The enzyme also decreased the changes of total shrinking during aging. Other recent examples are provided in Table 10.

\section{CONCLUSIONS}

The use of enzymes in the food industry is a well-established approach, in particular due to the specificity of enzyme action and their green, environmentally friendly nature. Still there is a constant urge for process improvement and/or for the development of novel processes or products that pushes industry to

Table 10 | Xylanases from marine sources.

\begin{tabular}{|c|c|c|c|}
\hline Source & $\begin{array}{l}\mathrm{pH}(-) \text { and temperature optima } \\
\left({ }^{\circ} \mathrm{C}\right) \text { and activity }\end{array}$ & Comments & References \\
\hline $\begin{array}{l}\text { XynA gene from } \\
\text { Glaciecola mesophila } \\
\text { KMM } 241 \text { expressed } \\
\text { in E. coli }\end{array}$ & $\begin{array}{l}\text { 7.0; } 30 . \text { High activity in } 5.0<\mathrm{pH}< \\
9.0 \text { and } 20<T<35\end{array}$ & $\begin{array}{l}\text { Stable at } 20^{\circ} \mathrm{C} \text { for } 60 \mathrm{~min} \text {, but fully deactivated after } 20 \mathrm{~min} \text { at } 40^{\circ} \mathrm{C} \text {. } \\
\text { Useful if the enzyme is used as additive in dough processing, since } \\
\text { it is denatured and deactivated during bread baking. High stability } \\
\text { within } \mathrm{pH} 6.0 \text { to } 8.0 \\
\text { Activity peaks for } \mathrm{NaCl} \text { within } 0.5 \text { to } 1.0 \mathrm{M} \text {, then decreases to } 50 \% \\
\text { of the residual activity (with } 0 \mathrm{M} \mathrm{NacL} \text { as reference) at } 4.0 \mathrm{M} \mathrm{NaCl.I} \\
\text { Activity stimulated by } \mathrm{Ca}^{2+}, \mathrm{EDTA}(1 \mathrm{mM} \text { and } 10 \mathrm{mM} \text {, each); rougly } \\
\text { unaffected by } \mathrm{Sr}^{2+}, \mathrm{Mg}^{2+}\left(1 \mathrm{mM} \text { and } 10 \mathrm{mM}, \text { each) and } \mathrm{Cu}^{2+}\right. \\
(1 \mathrm{mM}) \text {; inhibited by } \mathrm{Ba}^{2+}, \mathrm{Ca}^{2+}, \mathrm{Co}^{2+}, \mathrm{Ni}^{2+}, \mathrm{Mn}^{2+}, \mathrm{Fe}^{3+}, \mathrm{Sn}^{2+} \text {, } \\
\mathrm{Zn}{ }^{2+}, \mathrm{SDS}\left(1 \mathrm{mM} \text { and } 10 \mathrm{mM} \text {, each) and } \mathrm{Cu}^{2+}(10 \mathrm{mM})\right. \\
\text { When tested in bread making, the enzyme displayed } \\
\text { dough-softening ability, improved by } 30 \% \text { bread volume, was } \\
\text { effective in reducing initial and displayed anti-staling effect on bread. } \\
\text { In the overall the enzyme showed clear potential to be used in the } \\
\text { bread making process }\end{array}$ & $\begin{array}{l}\text { Guo et al., 2009; } \\
\text { Zheng et al., } \\
2011\end{array}$ \\
\hline
\end{tabular}

XynB gene from

Glaciecola mesophila

KMM 241 expressed

in E. coli
6.0-7.0; 35. High activity in $6.0<\mathrm{pH}$ $<10.0$ and $20<T<35$
As observed with the xylanase expressed by the XynA gene, the enzyme was stable at $20^{\circ} \mathrm{C}$ for $60 \mathrm{~min}$. It deactivated fully after $20 \mathrm{~min}$ at $45^{\circ} \mathrm{C}$. Useful if the enzyme is used as additive in dough processing, since it is denatured and deactivated during bread baking. High stability within $\mathrm{pH} 6.0$ to 10.0 , hence more stable in alkaline environment than the enzyme expressed by the XynA gene. Unlike observed with the later enzyme, the activity of the xylanase expressed by $\mathrm{XynB}$ gene gradually decreases as $\mathrm{NaCl}$ concentration (M) increases from 0.0 to 4.0 Still at $4.0 \mathrm{M} \mathrm{NaCl}$, the enzyme retains $40 \%$ of the residual acivity. The enzyme required a minimum of five sugar moieties for effective hydrolysis Activity rougly unaffected by urea (1 and $5 \mathrm{mM}), \mathrm{K}^{+}(1 \mathrm{mM})$ and $\mathrm{Sn}^{2+}(5 \mathrm{mM})$; inhibited by $\mathrm{Ca}^{2+}, \mathrm{Cu}^{2+}, \mathrm{Li}^{+}, \mathrm{Mg}^{2+}, \mathrm{Co}^{2+}, \mathrm{Ni}^{2+}$, $\mathrm{Mn}^{2+}, \mathrm{Fe}^{3+}, \mathrm{Sr}^{2+}, \mathrm{Zn}^{2+}$, EDTA, SDS (1 mM and $5 \mathrm{mM}$, each) $\mathrm{K}^{+}$ $(5 \mathrm{mM})$ and $\mathrm{Sn}^{2+}(1 \mathrm{mM})$

Activity peaked at $0.5 \mathrm{M} \mathrm{NaCl}$. Activitystimulated by $\mathrm{Ca}^{2+}, \mathrm{Co}^{2+}$ and $\mathrm{Zn}^{2+}\left(1 \mathrm{mM}\right.$, each); inhibited by $\mathrm{Cu}^{2+}, \mathrm{Mg}^{2+}, \mathrm{Mn}^{2+}, \mathrm{Fe}^{3+}$ and EDTA (1 $\mathrm{mM}$, each) Guo et al., 2013 
find new alternatives, including some out of the box approaches. The marine environment, particularly at the microbial level, has been relatively unexploited, but its potential as source of biological agents with application in several relevant fields in the world economy has been acknowledged. This review illustrated how marine enzymes and food industry can intertwine. To do so, the role of key enzymes in relevant applications was illustrated and recent findings on enzymes isolated that display catalytic activity that fit in such applications were disclosed. The use of marine enzymes can result in improved or new processes or products as a result of their nature. Thus, these enzymes can display the required, eventually novel, catalytic activity under operational conditions of temperature or salinity, among others, which may provide a competitive edge in either process or product development and readiness to market. The review focused mostly in microbially produced enzymes, since microorganism are easier and cheaper to grow than mammalian or plant cells and provide a higher yield and productivity in the targeted enzyme. Moreover, the review also discloses that the production of several marine enzymes of interest is carried out after cloning and expression in a heterologous host, viz. E. coli, again taking into consideration ease of production and productivity yields, which are related to the detailed existing knowledge on the omic characteristics of the host. In the overall, this strategy has been clearly improved by turning to metagenomic libraries, that furthermore allow the access to unculturable microorganisms, actually the vast majority of the microbiota. In many cases presented the kinetic and stability features of marine enzymes has been just unveiled through the use of model systems, still of common use within the scope of application in the food industry. Other enzymes from marine sources have already been used for processes and products already implemented to commercial scale.

In the overall, it can be considered that the marine microbiota is a promising source of enzymes with application in the food industry and efforts toward further developments in this particular field are prone to meet success. It is likely that in the short term efforts may involve the design of cost effective processes anchored in the most effective enzyme candidates, as this will provide the necessary leverage to attract industrial alongside with academic partners, a connection favored for effective and practical developments.

\section{REFERENCES}

Afinah, S., Yazid, A. M., Anis Shobirin, M. H., and Shuhaimi, M. (2010). Phytase: application in food industry. Int. Food Res. J. 17, 13-21.

Aguilar, C. N., and Gutierrez-Sanchez, G. (2001). Review: sources, properties, applications and potential uses of Tannin Acyl Hydrolase. Food Sci. Technol. Int. 7, 373-382. doi: 10.1106/69M3-B30K-CF 7Q-RJ5G

Aiyer, P. V. (2005). Amylases and their applications. Afr. J. Biotechnol. 4, 1525-1529. Aravindan, R., Anbumathi, P., and Viruthagiri, T. (2007). Lipase applications in food industry. Indian J. Biotechnol. 6, 141-158.

Arnosti, C., Bell, C., Moorhead, D. L., Sinsabaugh, R. L., Steen, A. D., Stromberger, M., et al. (2014). Extracellular enzymes in terrestrial, freshwater, and marine environments: perspectives on system variability and common research needs. Biogeochemistry 117, 5-21. doi: 10.1007/s10533-0139906-5

Atichokudomchai, N., Jane, J.-1., and Hazlewood, G. (2006). Reaction pattern of a novel thermostable $\alpha$-amylase. Carbohydr. Polymers 64, 582-588. doi: 10.1016/j.carbpol.2005.11.014
Basso, A., Spizzo, P., Ferrario, V., Knapic, L., Savko, N., Braiuca, P., et al. (2010). Endo- and exo-inulinases: enzyme-substrate interaction and rational immobilization. Biotechnol. Prog. 26, 397-405. doi: 10.1002/btpr.33

Bauvois, C., Jacquamet, L., Huston, A. L., Borel, F., Feller, G., and Ferrer, J. L. (2008). Crystal Structure of the Cold-active Aminopeptidase from Colwellia psychrerythraea, a Close Structural Homologue of the Human Bifunctional Leukotriene A4 Hydrolase. J. Biol. Chem. 283, 23315-23325. doi: 10.1074/jbc.M802158200

Beena, P. S., Soorej, M. B., Elyas, K. K., Sarita, G. B., and Chandrasekaran, M. (2010). Acidophilic Tannase from Marine Aspergillus awamori BTMFW032. J. Microbiol. Biotechnol. 20, 1403-1414. doi: 10.4014/jmb.1004.04038

Beena, P. S., Soorej, M. B., Sarita, G. B., Bahkali, A. H., and Chandrasekaran, M. (2011). Propyl gallate synthesis using acidophilic tannase and simultaneous production of tannase and gallic acid by marine Aspergillus awamori BTMFW032. Appl. Biochem. Biotechnol. 164, 612-628. doi: 10.1007/s12010-011-9162-x

Beg, Q. K., Kapoor, M., Mahajan, L., and Hoondal, G. S. (2001). Microbial xylanases and their industrial applications: a review. Appl. Microbiol. Biotechnol. 56, 326-338. doi: 10.1007/s002530100704

Bekhit, A. A., Hopkins, D. L., Geesink, G., Bekhit, A. A., and Franks, P. (2013). Exogenous proteases for meat tenderization. Crit. Rev. Food Sci. Nutr. 54, 1012-1031. doi: 10.1080/10408398.2011.623247

Belancic, A., Gunata, Z., Vallier, M. J., and Agosin, E. (2003). $\beta$-glucosidase from the grape native yeast Debaryomyces vanrijiae: purification, characterization, and its effect on monoterpene content of a muscat grape juice. J. Agric. Food Chem. 51, 1453-1459. doi: 10.1021/jf0257771

Benediktsson, B., and Bjarnason, J. B. (2001). Protein hydrolysates produced with the use of marine proteases. WO Patent Application 2001028353 A2.

Bertoft, E. (2004). "Analysing starch structure," in Starch in Food - Structure, Function and Applications, ed A.-C. Eliasson (Cambridge: Woodhead Publishing Limited), 57-96.

Bhatia, Y., Mishra, S., and Bisaria, V. S. (2002). Microbial beta-glucosidases: cloning, properties, and applications. Crit. Rev. Biotechnol. 22, 375-407. doi: 10.1080/07388550290789568

Bindiya, P., and Ramana, T. (2012). Optimization of lipase production from an indigenously isolated marine Aspergillus sydowii of Bay of Bengal. J. Biochem. Technol. 3, S203-S211.

Blanchard, P. H., and Katz, F. R. (2006). "Starch hydrolysates," in Food Polysaccharides and Their Applications, eds A. M. Stephen, G. O. Phillips, and P. A. Williams (Boca Raton, FL: CRC Press), 119-145.

Bohlin, C., Praestgaard, E., Baumann, M. J., Borch, K., Praestgaard, J., Monrad, R. N., et al. (2013). A comparative study of hydrolysis and transglycosylation activities of fungal $\beta$-glucosidases. Appl. Microbiol. Biotechnol. 97, 159-169. doi: 10.1007/s00253-012-3875-9

Borchert, M., Gjermansen, M., Clark, S., Henrissat, B., Silow, M. B., and Hallin, P. F. (2011). Pullulanase variants and uses thereof. WIPO Patent Application WO/2011/087836 A2.

Chakraborty, S., Raut, G., Khopade, A., Mahadik, K., and Kokare, C. (2012). Study on calcium ion independent $\alpha$-amylase from haloalkaliphilic marine Streptomyces strain A3. Indian J. Biotechnol. 11, 427-437.

Chen, H., Yan, X., Zhu, P., and Lin, J. (2006). Antioxidant activity and hepatoprotective potential of agaro-oligosaccharides in vitro and in vivo. Nutrition J. 5, 31 . doi: 10.1186/1475-2891-5-31

Chen, X. L., Xie, B. B., Lu, J. T., He, H. L., and Zhang, Y. Z. (2007a). A novel type of subtilase from the psychrotolerant bacterium Pseudoalteromonas sp. SM9913: catalytic and structural properties of deseasin MCP-01. Microbiology 153, 2116-2125. doi: 10.1099/mic.0.2007/006056-0

Chen, X. L., Zhang, Y. Z., Gao, P. J., and Luan, X. W. (2003). Two different proteases produced by a deep-sea psychrotrophic strain Pseudoaltermonas sp. SM9913. Mar. Biol. 143, 989-993. doi: 10.1007/s00227-003-1128-2

Chen, X. L., Zhang, Y. Z., Lu, J. T., Xie, B. B., Sun, C. Y., and Guo, B. (2007b). Autolysis of a novel multidomain subtilase-cold-adapted deseasin MCP-01 is $\mathrm{pH}$-dependent and the surface loops in its catalytic domain, the linker, and the P_proprotein domain are susceptible to proteolytic attack. Biochem. Biophys. Res. Commun. 358, 704-709. doi: 10.1016/j.bbrc.2007.04.193

Chi, W. J., Chang, Y. K., and Hong, S. K. (2012). Agar degradation by microorganisms and agar-degrading enzymes. Appl. Microbiol. Biotechnol. 94, 917-930. doi: 10.1007/s00253-012-4023-2

Chu, X., He, H., Guo, C., and Sun, B. (2008). Identification of two novel esterases from a marine metagenomic library derived from South China Sea. Appl. Microbiol. Biotechnol. 80, 615-625. doi: 10.1007/s00253-008-1566-3 
Claverie-Martİn, F., and Vega-Hernàndez, M. (2007). "Aspartic proteases used in cheese making," in Industrial Enzymes, eds J. Polaina and A. MacCabe (New York, NY: Springer), 207-219.

Cui, F., Dong, S., Shi, X., Zhao, X., and Zhang, X.-H. (2014). Overexpression and characterization of a novel thermostable $\beta$-Agarase YM01-3, from marine bacterium Catenovulum agarivorans $\mathrm{YM} 01^{T}$. Mar. Drugs 12, 2731-2747. doi: $10.3390 / \mathrm{md} 12052731$

Dar, Y. L. (2014). "Starches as food texturizing systems," in Functionalizing Carbohydrates for Food Applications, ed M. E. Embuscado (Lancaster, PA: DEStech Publications, Inc.), 41-79.

Delattre, C., Fenoradosoa, T. A., and Michaud, P. (2011). Galactans: an overview of their most important sourcing and applications as natural polysaccharides. Braz. Arch. Biol. Technol. 54, 1075-1092. doi: 10.1590/S151689132011000600002

Dionisi, H. M., Lozada, M., and Olivera, N. L. (2012). Bioprospection of marine microorganisms: biotechnological applications and methods. Rev. Argentina Microbiol. 44, 49-60. doi: 10.1590/S0325-75412012000100010

El-Gendy, M. M. A. (2012). Production of glucoamylase by marine endophytic Aspergillus sp. JAN-25 under optimized solid-state fermentation conditions on agro residues. Aust. J. Basic Appl. Sci. 6, 41-54.

Enoki, T., Okuda, S., Kudo, Y., Takashima, F., Sagawa, H., and Kato, I. (2010). Oligosaccharides from agar inhibit pro-inflammatory mediator release by inducing heme oxygenase 1. Biosci. Biotechnol. Biochem. 74, 766-770. doi: 10.1271/bbb. 90803

Farnet, A. M., Criquet, S., Pocachard, E., Gil, G., and Ferre, E. (2002). Purification of a new isoform of laccase from a Marasmius quercophilus strain isolated from a cork oak litter (Quercus suber L). Mycologia 94, 735-740. doi: 10.2307/ 3761687

Fernandes, P. (2010a). Enzymes in food processing: a condensed overview on strategies for better biocatalysts. Enzyme Res. 2010, 862537. doi: 10.4061/2010/ 862537

Fernandes, P. (2010b). "Enzymes in sugar industries," in Enzymes in Food Processing: Fundamentals and Potential Applications, eds P. Panesar, S. S. Marwaha and H. K. Chopra (New Delhi:.K. International Publishing House), 165-197.

Ferreira-Dias, S., Sandoval, G., Plou, F., and Valero, F. (2013). The potential use of lipases in the production of fatty acid derivatives for the food and nutraceutical industries. Elect. J. Biotechnol. 16, 1-38. doi: 10.2225/vol16-issue3-fulltext-5

Flament, D., Barbeyron, T., Jam, M., Potin, P., Czjzek, M., Kloareg, B., et al. (2007). Alpha-agarases define a new family of Glycoside Hydrolases, distinct from beta-agarase families. Appl. Environ. Microbiol. 73, 4691-4694. doi: 10.1128/AEM.00496-07

Freitas, A. C., Rodrigues, D., Rocha-Santos, T. A., Gomes, A. M., and Duarte, A. C. (2012). Marine biotechnology advances towards applications in new functional foods. Biotechnol. Adv. 30, 1506-1515. doi: 10.1016/j.biotechadv.2012.03.006

Fu, X. T., and Kim, S. M. (2010). Agarase: review of major sources, categories, purification method, enzyme characteristics and applications. Mar. Drugs 26 , 200-218. doi: 10.3390/md8010200

Fulzele, R., DeSa, E., Yadav, A., Shouche, Y., and Bhadekar, R. (2011). Characterization of novel extracellular protease produced by marine bacterial isolate from the Indian Ocean. Braz. J. Microbiol. 42, 1364-1373. doi: $10.1590 /$ S1517-83822011000400018

Gantelet, H., and Duchiron, F. (1998).Purification and properties of a thermoactive and thermostable pullulanase from Thermococcus hydrothermalis, a hyperthermophilic archaeon isolated from a deep-sea hydrothermal vent. Appl. Microbiol. Biotechnol. 49, 770-777. doi: 10.1007/s002530051245

Gao, L., Chi, Z., Sheng, J., Wang, L., Li, J., and Gong, F. (2007). Inulinase-producing marine yeasts: evaluation of their diversity and inulin hydrolysis by their crude enzymes. Microb. Ecol. 54, 722-729. doi: 10.1007/s00248-007-9231-4

Gelse, K., Pöschl, E., and Aigner, T. (2003). Collagens - Structure, function, and biosynthesis. Adv. Drug Deliv. Rev. 28, 1531-1546. doi: 10.1016/j.addr.2003.08.002

Goyal, K., Selvakumar, P., and Hayashi, K. (2001). Characterization of a thermostable $\beta$-glucosidase (BglB) from Thermotoga maritima showing transglycosylation activity. J. Mol. Catal. B Enzymatic 15, 45-53. doi: 10.1016/S1381$1177(01) 00003-0$

Gudmundsdottir, A. B. J. (2007). "Applications of cold adapted proteases in the food industry," in Novel Enzyme Technology for Food Applications, ed B. Rastall (Cambridge: Woodhead Publishing Limited), 205-214.
Günata, Z. (2003). "Flavor enhancement in fruit juices and derived beverages by exogenous glycosidases and consequences of the use of enzyme preparations," in The Handbook of Food Enzymology, eds J. R. Whitaker, A. G. J. Voragen, and D. W. S. Wong (New York, NY: Marcel Dekker,Inc.), 303-330.

Guo, B., Chen, X. L., Sun, C. Y., Zhou, B. C., and Zhang, Y. Z. (2009). Gene cloning, expression and characterization of a new cold-active and salt-tolerant endobeta-1,4-xylanase from marine Glaciecola mesophila KMM 241. Appl. Microbiol. Biotechnol. 84, 1107-1115. doi: 10.1007/s00253-009-2056-y

Guo, B., Li, P. Y., Yue, Y. S., Zhao, H. L., Dong, S., Song, X. Y., et al. (2013). Gene cloning, expression and characterization of a novel xylanase from the marine bacterium, Glaciecola mesophila KMM241. Mar. Drugs 11, 1173-1187. doi: $10.3390 / \mathrm{md} 11041173$

Guo, M. (2009). Functional Foods: Principles and Technology. Cambridge: Woodhead Publishing. doi: 10.1533/9781845696078

Gupta, R. S., and Bhandari, V. (2011). Phylogeny and molecular signatures for the phylum Thermotogae and its subgroups. Antonie van Leeuwenhoek 100, 1-34. doi: 10.1007/s10482-011-9576-z

Gurumurthy, D. M., and Neelagund, S. E. (2012). Molecular characterization of industrially viable extreme thermostable novel $\alpha$-amylase of Geobacillus sp. Iso5 Isolated from Geothermal Spring. J. Pure Appl. Microbiol. 6, 1759-1773. doi: 10.1007/s10989-012-9303-2

Han, W. J., Gu, J. Y., Liu, H. H., Li, F. C., Wu, Z. H., and Li, Y. Z. (2013). An extra peptide within the catalytic module of a $\beta$-agarase affects the agarose degradation pattern. J. Biol. Chem. 288, 9519-9531. doi: 10.1074/jbc.M112. 412247

Harris, A. D., and Ramalingam, C. (2010). Xylanases and its application in food industry: a review. J. Exp. Sci. 1, 1-11.

Hassairi, I., Amar, R. B., Nonus, M., and Gupta, B. B. (2001). Production and separation of $\alpha$-agarase from Altermonas agarlyticus strain GJ1B. Bioresource Technol. 79, 47-51. doi: 10.1016/S0960-8524(01)00037-2

Hehemann, J. H., Correc, G., Thomas, F., Bernard, T., Barbeyron, T., Jam, M., et al. (2012). Biochemical and structural characterization of the complex agarolytic enzyme system from the marine bacterium Zobellia galactanivorans. J. Biol. Chem. 287, 30571-30584. doi: 10.1074/jbc.M112.377184

Helland, R., Larsen, R. L., and Ásgeirsson, B. (2009). The $1.4 \AA$ crystal structure of the large and cold-active Vibrio sp. alkaline phosphatase. Biochim. Biophys. Acta 1794, 297-308. doi: 10.1016/j.bbapap.2008.09.020

Henrissat, B. (1991). A classification of glycosyl hydrolases based on amino acid sequence similarities. Biochem. J. 280, 309-316.

Hii, S. L., Tan, J. S., Ling, T. C., and Ariff, A. B. (2012). Pullulanase: role in starch hydrolysis and potential industrial applications. Enzyme Res. 2012, 921362. doi: $10.1155 / 2012 / 921362$

Hu, Z., Lin, B.-K., Xu, Y., Zhong, M. Q., and Liu, G.-M. (2009). Production and purification of agarase from a marine agarolytic bacterium Agarivorans sp. HZ105. J. Appl. Microbiol. 106, 181-190. doi: 10.1111/j.1365-2672.2008. 03990.x

Huang, X., Zhao, Y., Dai, Y., Wu, G., Shao, Z., Zeng, Q., et al. (2012). Cloning and biochemical characterization of a glucosidase from a marine bacterium Aeromonas sp. HC11e-3. World J. Microbiol. Biotechnol. 28, 3337-3344. doi: 10.1007/s11274-012-1145-8

Huston, A. L., Methe, B., and Deming, J. W. (2004). Purification, characterization, and sequencing of an extracellular cold-active aminopeptidase produced by marine psychrophile Colwellia psychrerythraea Strain 34H. Appl. Environ. Microbiol. 70, 3321-3328. doi: 10.1128/AEM.70.6.3321-3328.2004

Imhoff, J. F., Labes, A., and Wiese, J. (2011). Bio-mining the microbial treasures of the ocean: new natural products. Biotechnol. Adv. 29, 468-482. doi: 10.1016/j.biotechadv.2011.03.001

Jaeger, K. E., Dijkstra, B. W., and Reetz, M. T. (1999). Bacterial biocatalysts:molecular biology, three-dimensional structures, and biotechnological applications of lipases. Annu. Rev. Microbiol. 53, 315-351. doi: 10.1146/annurev.micro.53.1.315

Jeon, J. H., Kim, J. T., Lee, H. S., Kim, S.-J., Kang, S. G., Choi, S. H., et al. (2011). Novel lipolytic enzymes identified from metagenomic library of deepsea sediment. Evid. Based Complement. Alternat. Med. 2011, 271419. doi: $10.1155 / 2011 / 271419$

Jeon, J. H., Lee, H. S., Kim, J. T., Kim, S. J., Choi, S. H., Kang, S. G., et al. (2012) Identification of a new subfamily of salt-tolerant esterases from a metagenomic library of tidal flat sediment. Appl. Microbiol. Biotechnol. 93, 623-631. doi: 10.1007/s00253-011-3433-x 
Jiang, X., Huo, Y., Cheng, H., Zhang, X., Zhu, X., and Wu, M. (2012b). Cloning, expression and characterization of a halotolerant esterase from a marine bacterium Pelagibacterium halotolerans B2T. Extremophiles 16, 427-435. doi: 10.1007/s00792-012-0442-3

Jiang, X., Xu, X., Huo, Y., Wu, Y., Zhu, X., Zhang, X., et al. (2012a). Identification and characterization of novel esterases from a deep-sea sediment metagenome. Arch. Microbiol. 194, 207-214. doi: 10.1007/s00203-011-0745-2

Jiang, Z., Le Bail, A., and Wu, A. (2008). Effect of the thermostable xylanase B (XynB) from Thermotoga maritima on the quality of frozen partially baked bread. J. Cereal Sci. 47, 172-179. doi: 10.1016/j.jcs.2007.03.013

Jonghee, K., and Hon, S.-K. (2012). Isolation and characterization of an agaraseproducing bacterial strain, Alteromonas sp. GNUM-1, from the West Sea, Korea. J. Microbiol. Biotechnol. 22, 1621-1628. doi: 10.4014/jmb.1209.08087

Kang, W., Xu, Y., Qin, L., and Wang, Y. (2010). Effects of Different $\beta$-DGlycosidases on bound aroma compounds in muscat grape determined by HSSPME and GC-MS. J. Inst. Brewing 116, 70-77. doi: 10.1002/j.2050-0416.2010. tb00400.x

Kango, N., and Jain, S. C. (2011). Production and properties of microbial inulinases: recent advances. Food Biotechnol. 25, 165-212. doi: 10.1080/08905436. 2011.590763

Kennedy, J., Flemer, B., Jackson, S. A., Lejon, D. P. H., Morrissey, J. P., O’Gara, F., et al. (2010). Marine metagenomics: new tools for the study and exploitation of marine microbial metabolism. Mar. Drugs 8, 608-628. doi: 10.3390/ md8030608

Kerkhoffs, P. L. (1981). Preparation of fructose. US patent 4277563.

Khan, S., Pozzo, T., Megyeri, M., Lindahl, S., Sundin, A., Turner, C., et al. (2011). Aglycone specificity of Thermotoga neapolitana $\beta$-glucosidase $1 \mathrm{~A}$ modified by mutagenesis, leading to increased catalytic efficiency in quercetin-3-glucoside hydrolysis. BMC Biochem. 12:11. doi: 10.1186/1471-2091-12-11

Klomklao, S. (2008). Digestive proteinases from marine organisms and their applications. Songklanakarin J. Sci. Technol. 30, 37-46.

Klotz, A., Brown, K. M., and Zaretsky, E. M. (2010). Microbial trypsin mutants having chymotrypsin activity and nucleic acids encoding same. US Patent Application 20100151515 Al.

Korhonen, H. (2009). Milk-derived bioactive peptides: from science to applications. J. Funct. Foods 1, 177-187. doi: 10.1016/j.jff.2009.01.007

Kumar, P. S., Ghosh, M., Pulicherla, K. K., and Rao, K. R. S. S. (2011). Cold active enzymes from the marine psychrophiles: biotechnological perspective. Adv. Biotech. 10, 16-20.

Leary, D., Vierros, M., Hamon, G., Arico, S., and Monagle, C. (2009). Marine genetic resources: a review of scientific and commercial interest. Mar. Policy 33, 183-194. doi: 10.1016/j.marpol.2008.05.010

Lee, Y. H., Jun, S. E., and Shin, H. D. (2005). Low molecular weight agarose-specific alpha-agarase from agarolytic marine microorganism Pseudoalteromonas sp. BL-3 which hydrolyzes alpha-1,3-glycoside bond of agar or agarose to produce agarobiose and agarotetraose. Patent KR2005079035-A.

Lee, Y., Oh, C., De Zoysa, M., Kim, H., Wickramaarachchi, W. D. N., Whang, I., et al. (2013). molecular cloning, overexpression, and enzymatic characterization of glycosyl hydrolase family $16 \beta$-agarase from marine bacterium Saccharophagus sp. AG21 in Escherichia coli. J. Microbiol. Biotechnol. 23, 913-922. doi: 10.4014/jmb.1209.09009

Li, A.-X., Guo, L.-Z., and Lu, W.-D. (2012). Alkaline inulinase production by a newly isolated bacterium Marinimicrobium sp. LS-A18 and inulin hydrolysis by the enzyme. World J. Microbiol. Biotechnol. 28, 81-89. doi: 10.1007/s11274-0110794-3

Li, H., Chi, Z., Duan, X., Wang, L., Sheng, J., and Wu, L. (2007). Glucoamylase production by the marine yeast Aureobasidium pullulans N13d and hydrolysis of potato starch granules by the enzyme. Process Biochem. 42, 462-465. doi: 10.1016/j.procbio.2006.09.012

Li, P. Y., Ji, P., Li, C. Y., Zhang, Y., Wang, G. L., and Zhang, X. Y. (2014). Structural basis for dimerization and catalysis of a novel esterase from the GTSAG motif subfamily of the bacterial hormone-sensitive lipase family. J. Biol. Chem. 289, 19031-19041. doi: 10.1074/jbc.M114.574913

Li, X., Chi, Z., Liu, Z., Yan, K., and Li, H. (2008). Phytase production by a marine yeast Kodamea ohmeri BG3. Appl. Biochem. Biotechnol. 149, 183-193. doi: 10.1007/s12010-007-8099-6

Liang, Q. (2005). "Understanding starches and their roles in foods", in Food Carbohydrates Chemistry, Physical Properties, and Applications, ed S. W. Cui (Boca Raton, FL: CRC Press), 309-355.
Lima, D. M., Fernandes, P., Nascimento, D. S., Ribeiro, R. C. L. F., and de Assis, S. A. A. (2011). Fructose syrup: a biotechnology asset. Food Technol. Biotechnol. 49, 424-434.

Longo, M. A., and Sanromán, M. A. (2006). Production of food aroma compounds: microbial and enzymatic methodologies. Food Technol. Biotechnol. 44, 335-353

Lu, W.-D., Li, A.-X., and Guo, Q.-L. (2014). Production of novel alkalitolerant and thermostable inulinase from marine actinomycete Nocardiopsis $\mathrm{sp}$. DNK15 and inulin hydrolysis by the enzyme. Ann. Microbiol. 64, 441-449. doi: 10.1007/s13213-013-0674-1

Lundemo, P., Adlercreutz, P., and Karlsson, E. N. (2013). Improved transferase/hydrolase ratio through rational design of a family $1 \beta$-glucosidase from Thermotoga neapolitana. Appl. Environ. Microbiol. 79, 3400-3405. doi: 10.1128/AEM.00359-13

Mao, X., Hong, Y., Shao, Z., Zhao, Y., and Liu, Z. (2010). A novel cold-active and alkali-stable $\beta$-glucosidase gene isolated from the marine bacterium Martelella mediterranea. Appl. Biochem. Biotechnol. 162, 2136-2148. doi: 10.1007/s12010010-8988-y

Meenakshi, S., Umayaparvathi, S., Manivasagan, P., Arumugam, M., and Balasubramanian, T. (2013). Purification and characterization of inulinase from marine bacterium Bacillus cereus MU-31. Indian J.Geo-Marine Sci. 42, 510-515.

Miguel, A. S. M., Martins-Meyer, T. S., Figueiredo, E. V. C., Lobo, V. W. P., and Dellamora-Ortiz, G. M. (2013). "Enzymes in bakery: current and future trends," in Food Industry, ed I. Muzzalupo (e-book, InTech). Available onlineat: http://www.intechopen.com/books/food-industry/ enzymes-in-bakery-current-and-future-trends

Mikkelson, A., Maaheimo, H., and Hakala, T. (2013). Hydrolysis of konjac glucomannan by Trichoderma reesei mannanase and endoglucanases Cel7B and Cel5A for the production of glucomannooligosaccharides. Carbohydrate Res. 372, 60-68. doi: 10.1016/j.carres.2013.02.012

Minegishi, H., Shimane, Y., Echigo, A., Ohta, Y., Hatada, Y., Kamekura, M., et al. (2013). Thermophilic and halophilic $\beta$-agarase from a halophilic archaeon Halococcus sp. 197A. Extremophiles 17, 931-939. doi: 10.1007/s00792-0130575-Z

Mittal, A., Gupta, V., Singh, G., Yadav, A., and Aggarwal, N. K. (2013). Phytase: a boom in food industry. Octa J. Biosci. 1, 158-169.

Mohankumar, A., and Ranjitha, P. (2010). Purification and characterization of esterase from marine Vibrio fischeri isolated from squid. Indian J. Mar. Sci. 39, 262-269.

Mojsov, K. (2013). Use of enzymes in wine making: a review. Int. J. Market. Technol. 3, 112-127.

Molkabadi, E. Z., Hamidi-Esfahani, Z., Sahari, M. A., and Hosein Azizi, M. (2013). A new native source of tannase producer, Penicillium sp. EZ-ZH190: characterization of the enzyme. Iran. J. Biotechnol. 11, 244-250. doi: 10.5812/ijb.11848

Nakaya, K., Ohtara, K., Okamoto, T., Yamada, N., and Kaga, C. (2010). Low-protein food and manufacturing method for same. Patent application US20100316762 A1

Nedwin, G., Sharma, V., and Shetty, J. (2011). $\alpha$-Amylase blend for starch processing and use thereof Patent application. WO 2011017093 A1.

Ni, X., Yue, L., Chi, Z., Li, J., Wang, X., and Madzak, C. (2009). Alkaline protease gene cloning from the marine yeast Aureobasidium pullulans HN2-3 and the protease surface display on Yarrowia lipolytica for bioactive peptide production. Mar. Biotechnol. 11, 81-89. doi: 10.1007/s10126-008-9122-9

Nielsen, M. K., and Nielsen, H. H. (2012). “Seafood enzymes," in Food Biochemistry and Food Processing, eds L. Simpson, F. Nollet, B. Soottawat, P. Gopinadhan, and Y. Hui (Ames, IA: Wiley-Blackwell), 247-262.

Ohta, Y., Hatada, Y., Miyazaki, M., Nogi, Y., Ito, S., and Horikoshi, K. (2005). Purification and characterization of a Novel $\alpha$-agarase from a Thalassomonas sp. Curr. Microbiol. 50, 212-216. doi: 10.1007/s00284-004-4435-z

Palanisami, S., Kannan, K., and Lakshmanan, U. (2012). Tannase activity from the marine cyanobacterium Phormidium valderianum BDU140441. J. Appl. Phycol. 24, 1093-1098. doi: 10.1007/s10811-011-9738-4

Pancha, I., Jain, D., Shrivastav, A., Mishra, S. K., Shethia, B., Mishra, S., et al. (2010). A thermoactive $\alpha$-amylase from a Bacillus sp. isolated from CSMCRI salt farm. Int. J. Biol. Macromol. 47, 288-291. doi: 10.1016/j.ijbiomac.2010. 04.006

Panda, T., and Gowrishankar, B. S. (2005). Production and applications of esterases. Appl. Microbiol. Biotechnol. 67, 160-169. doi: 10.1007/s00253-004-1840-y

Paravidino, M., Böhm, P., Gröger, H., and Hanefeld, U. (2012). "Hydrolysis and formation of carboxylic acid esters," in Enzyme Catalysis in Organic Synthesis: 
A Comprehensive Handbook, eds K. Drauz, H. Gröger, and O. May (Weinheim: Wiley-VCH Verlag and Co KGaA), 249-361.

Parker, K., Salas, M., and Nwosu, V. C. (2010). High fructose corn syrup: production, uses and public health concerns. Biotechnol. Mol. Biol. Rev. 5, 71-78

Peng, Q., Wang, X., Shang, M., Huang, J., Guan, G., Li, Y., et al. (2014). Isolation of a novel alkaline-stable lipase from a metagenomic library and its specific application for milkfat flavor production. Microb. Cell Fact. 13, 1-9. doi: 10.1186/1475-2859-13-1

Potin, P., Richard, C., Rochas, C., and Kloareg, B. (1993). Purification and characterization of the $\alpha$-agarase from Alteromonas agarlyticus (Cataldi) comb. nov., strain GJ1B. Eur. J. Biochem. 214, 599-607. doi: 10.1111/j.14321033.1993.tb17959.x

Pozzo, T., Pasten, J. L., Karlsson, E. N., and Logan, D. T. (2010). Structural and functional analyses of beta-glucosidase $3 \mathrm{~B}$ from Thermotoga neapolitana: a thermostable three-domain representative of glycoside hydrolase 3. J. Mol. Biol. 397, 724-739. doi: 10.1016/j.jmb.2010.01.072

Ramnani, P., Chitarrari, R., Tuohy, K., Grant, J., Hotchkiss, S., Philp, K., et al. (2012). In vitro fermentation and prebiotic potential of novel low molecular weight polysaccharides derived from agar and alginate seaweeds. Anaerobe 18, 1-6. doi: 10.1016/j.anaerobe.2011.08.003

Ran, L. Y., Su, H. N., Zhao, G. Y., Gao, X., Zhou, M. Y., Wang, P., et al. (2013). Structural and mechanistic insights into collagen degradation by a bacterial collagenolytic serine protease in the subtilisin family. Mol. Microbiol. 90, 997-1010. doi: $10.1111 / \mathrm{mmi} .12412$

Ran, L. Y., Su, H. N., Zhou, M. Y., Wang, L., Chen, X. L., Xie, B. B., et al. (2014). Characterization of a novel subtilisin-like protease myroicolsin from deep sea bacterium Myroides profundi D25 and molecular insight into its collagenolytic mechanism. J. Biol. Chem. 289, 6041-6053. doi: 10.1074/jbc.M113.513861

Ricca, E., Calabr,ò, V., Curcio, S., and Iorio, G. (2007). The state of the art in the production of fructose from inulin enzymatic hydrolysis. Crit. Rev. Biotechnol. 27, 129-145. doi: 10.1080/07388550701503477

Sawant, R., and Nagendran, S. (2014). Protease: an enzyme with multiple industrial applications. World J. Pharm. Pharm. Sci. 3, 568-579.

Schwerdtfeger, R. M., Chiaraluce, R., Consalvi, V., Scandurra, R., and Antranikian, G. (1999). Stability, refolding and $\mathrm{Ca}^{2+}$ binding of pullulanase from the hyperthermophilic archaeon Pyrococcus woesei. Eur. J. Biochem. 264, 479-487. doi: 10.1046/j.1432-1327.1999.00640.x

Seok, J. H., Kim, H.-S., Hatada, Y., Nam, S.-W., and Kim, Y.-H. (2012). Construction of an expression system for the secretory production of recombinant $\alpha$-agarase in yeast. Biotechnol. Lett. 34, 1041-1049. doi: 10.1007/s10529012-0864-0

Sharma, M., and Kumar, A. (2013). Xylanases: an overview. Br. Biotechnol. J. 3, 1-28. doi: 10.9734/BBJ/2013/1784

Sriram, N., Priyadharshini, M., and Sivasakthi, S. (2012). Production and characterization of amino peptidase from marine aspergillus flavus. Int. J. Microbiol. Res. 3, 221-226. doi: 10.5829/idosi.ijmr.2012.3.3.66171

Singh, A., Das, M., Bal, S., and Banerjee, R. (2014). "Rice processing," in Engineering Aspects of Cereal and Cereal-Based Products, eds R. P. F. Guiné and P. M. R. Correia (Boca Raton, FL: CRC Press), 71-95.

Steen, A. D., and Arnosti, C. (2013). Extracellular peptidase and carbohydrate hydrolase activities in an Arctic fjord (Smeerenburgfjord, Svalbard). Aquat. Microb. Ecol. 69, 93-99. doi: 10.3354/ame01625

Struvay, C., and Feller, G. (2012). Optimization to low temperature activity in psychrophilic enzymes. Int. J. Mol. Sci. 13, 11643-11665. doi: 10.3390/ijms130911643

Su, E., Xia, T., Gao, L., Dai, O., and Zhang, Z. (2010). Immobilization of Bglucosidase and its aromaincreasing effect on tea beverage. Food Bioproducts Proc. 88, 83-89. doi: 10.1016/j.fbp.2009.04.001

Sun, H., Xue, Y., and Lin, Y. (2014). Enhanced catalytic efficiency in Quercetin-4'glucoside Hydrolysis of Thermotoga maritima $\beta$-Glucosidase a by site-directed mutagenesis. J. Agric. Food Chem. 62, 6763-6770. doi: 10.1021/jf501932v

Takagi, H., Kondou, M., Tomoaki, H., Nakamori, S., Tsai, Y.-C. H., and Yamasaki, M. (1992). Effects of an alkaline elastase from an alkalophilic Bacillus strain on the tenderization of beef meat. J. Agric. Food Chem. 40, 2364-2368. doi: $10.1021 /$ jf00024a008

Temuujin, U., Chi, W. J., Chang, Y. K., and Hong, S. K. (2012). Identification and biochemical characterization of Sco3487 from Streptomyces coelicolor A3(2), an exo- and endo-type $\beta$-agarase-producing neoagarobiose. J. Bacteriol. 194, 142-149. doi: 10.1128/JB.05978-11
Tramice, A., Andreotti, G., and Trincone, A. (2011). Hydrosoluble antioxidants by enzymatic glucosylation of a vitamin $\mathrm{E}$ derivative using marine $\alpha$-D-Glucosidase from Aplysia fasciata. Mar. Biotechnol. 13, 773-781. doi: 10.1007/s10126-010-9339-2

Trincone, A. (2011). Marine biocatalysts: enzymatic features and applications. Mar. Drugs 9, 478-499. doi: 10.3390/md9040478

Trincone, A. (2013a). Biocatalytic processes using marine biocatalysts: ten cases in point. Curr. Org. Chem. 17, 1058-1066.

Trincone, A. (2013b). Angling for uniqueness in enzymatic preparation of glycosides. Biomolecules 3, 334-350. doi: 10.3390/biom3020334

Turner, P., Svensson, D., Adlercreutz, P., and Karlsson, E. N. (2007). A novel variant of Thermotoga neapolitana $\beta$-glucosidase B is an eficiente catalyst for the synthesis of alkyl glucosides by transglycosylation. J. Biotechnol. 130, 67-74. doi: 10.1016/j.jbiotec.2007.02.016

Uchiyama, T., Kawamura, M., Sashida, R., Ueda, M., Ohba, S., and Ohkishi, H. (2005). Method of manufacturing inulotriose and/or inulotetrose using an exotype hydrolase capable of hydrolyzinga fructan only every 3 or 4 sugar units from a terminal fructose. US patent 5122460.

Uzyol, K. S., Sarryar-Akbulut, B., Denizci, A. A., and Kazan, D. (2012). Thermostable $\alpha$-amylase from moderately halophilic Halomonas sp. AAD21. Turk. J. Biol. 36, 327-338. doi: 10.3906/biy-1106-7

Veltman, O. R., Vriend, G., Berendsen, H. J. C., Van den Burg, B., Venema, G. and Eijsink, V. G. H. (1998). A single calcium binding site is crucial for the calcium-dependent thermal stability of thermolysin-like proteases. Biochemistry 37, 5312-5319. doi: 10.1021/bi9725879

Vijayaraghavan, R., and Rajendran, S. (2012). Identification of a novel agarolytic $\gamma$-proteobacterium Microbulbifer maritimus and characterization of its agarase. J. Basic Microbiol. 52, 705-712. doi: 10.1002/jobm.201100315

Visser, J., Hinz, S., Verij, J., Visser, J., Joosten, V., Koetsier, M., et al. (2012). Novel fungal esterases. WIPO Patent Application WO/2012/078741 A2.

Wang, Y., Zhang, C., Li, J., and Xu, Y. (2013). Different in?uences of $\beta$ glucosidases on volatile compounds and anthocyanins of Cabernet Gernischt and possible reason. Food Chem. 140, 245-254. doi: 10.1016/j.foodchem.2013. 02.044

Ward, O. P., Rao, M. B., and Kulkarni, A. (2009). "Proteases," in Encyclopedia of Microbiology, Vol. 1, ed M. Schaechter (Oxford: Elsevier), 495-511.

Wu, S.-J., and Chen, J. (2014). Preparation of maltotriose from fermentation broth by hydrolysis of pullulan using pullulanase. Carbohydrate Pol. 107, 94-97. doi: 10.1016/j.carbpol.2014.02.050

Xie, W., Lin, B., Zhou, Z., Lu, G., Lun, J., Xia, C., et al. (2013). Characterization of a novel $\beta$-agarase from an agar-degrading bacterium Catenovulum sp. X3. Appl. Microbiol. Biotechnol. 97, 4907-4915. doi: 10.1007/s00253-012$4385-5$

Xu, J.-L., Lu, M.-S., Wang, S.-J., Li, H. Z., Sun, Y.-Y., and Fang, Y.-W. (2009). Production and characterization of pullulanase from hyperthermophilic archaeon Thermococcus sp.HJ21. J. Food Sci. Biotechnol. 2, 243-249.

Ye, M., Yu, C.-Y., Li, N., and Zong, M.-H. (2011). Highly regioselective glucosylation of 2'-deoxynucleosides by using the crude $\beta$-glycosidase from bovine liver. J. Biotechnol. 155, 203-208. doi: 10.1016/j.jbiotec.2011.06.031

Yuan, D., Lan, D., Xin, R., Yang, B., and Wang, Y. (2014). Biochemical properties of a new cold-active mono- and diacylglycerol lipase from marine member Janibacter sp. strain HTCC2649. Int. J. Mol. Sci. 15, 10554-10566. doi: 10.3390/ijms 150610554

Zhang, C., and Kim, S.-K. (2010). Research and application of marine microbial enzymes: status and prospects. Mar. Drugs 8, 1920-1934. doi: $10.3390 / \mathrm{md} 8061920$

Zhang, Z., Marquardt, R. R., Wang, G., Guenter, W., Crow, G. H., Han, Z., et al. (1996). A simple model for predicting the response of chicks to dietary enzyme supplementation. J. Anim. Sci. 74, 394-402.

Zhao, G. Y., Zhou, M. Y., Zhao, H. L., Chen, X. L., Xie, B. B., Zhang, X. Y., et al. (2012a). Tenderization effect of cold-adapted collagenolytic protease MCP01 on beef meat at low temperature and its mechanism. Food Chem. 134, 1738-1744. doi: 10.1016/j.foodchem.2012.03.118

Zhao, H. L., Chen, X. L., Xie, B. B., Zhou, M. Y., Gao, X., and Zhang, X. Y. (2012b). Elastolytic mechanism of a novel M23 metalloprotease pseudoalterin from deep-sea Pseudoalteromonas sp. CF6-2: cleaving not only glycyl bonds in the hydrophobic regions but also peptide bonds in the hydrophilic regions involved in cross-linking. J. Biol. Chem. 287, 39710-39720. doi: 10.1074/jbc.M112.405076 
Zhao, L., Budge, S. M., Ghaly, A. E., Brooks, M. S., and Dave, D. (2011). Extraction, purification and characterization of fish pepsin: a critical review. Food Process. Technol. 2, 1-14. doi: 10.4172/2157-7110.10 00126

Zheng, H., Guo, B., Chen, X. L., Fan, S. J., and Zhang, Y. Z. (2011). Improvement of the quality of wheat bread by addition of glycoside hydrolase family 10 xylanases. Appl. Microbiol. Biotechnol. 90, 509-515. doi: 10.1007/s00253-0113088-7

Conflict of Interest Statement: The author declares that the research was conducted in the absence of any commercial or financial relationships that could be construed as a potential conflict of interest.
Received: 07 August 2014; accepted: 14 September 2014; published online: 06 October 2014.

Citation: Fernandes P (2014) Marine enzymes and food industry: insight on existing and potential interactions. Front. Mar. Sci. 1:46. doi: 10.3389/fmars.2014.00046

This article was submitted to Marine Biotechnology, a section of the journal Frontiers in Marine Science.

Copyright (c) 2014 Fernandes. This is an open-access article distributed under the terms of the Creative Commons Attribution License (CC BY). The use, distribution or reproduction in other forums is permitted, provided the original author(s) or licensor are credited and that the original publication in this journal is cited, in accordance with accepted academic practice. No use, distribution or reproduction is permitted which does not comply with these terms. 